The Canadian Mineralogist

Vol. 41, pp. 185-200 (2003)

\title{
POLYMETALLIC SULFIDES AND SULFOSALTS OF THE PONGKOR EPITHERMAL GOLD-SILVER DEPOSIT, WEST JAVA, INDONESIA
}

\author{
I WAYAN WARMADA AND BERND LEHMANN \\ Institute of Mineralogy and Mineral Resources, Technical University of Clausthal, \\ Adolph-Roemer-Str. 2A, D-38678 Clausthal-Zellerfeld, Germany \\ MAROLOP SIMANDJUNTAK \\ PT Aneka Tambang (Persero), Unit Penambangan Emas Pongkor, Bogor, Indonesia
}

\begin{abstract}
The Pongkor gold-silver deposit, of Pliocene age $(2.05 \pm 0.05 \mathrm{Ma})$, is the largest low-sulfidation epithermal precious-metal deposit in Indonesia. It consists of nine major subparallel quartz - "adularia" - carbonate veins with a very low sulfide content. The association of sulfides is the main gold carrier and is dominated by pyrite, chalcopyrite, sphalerite, \pm galena (grey sulfide quartz stage). Minor phases are silver-rich sulfides and sulfosalts, such as acanthite-aguilarite $\left(\mathrm{Ag}_{2} \mathrm{~S}-\mathrm{Ag}_{4} \mathrm{SSe}\right)$, polybasitepearceite $\left[(\mathrm{Ag}, \mathrm{Cu})_{16}(\mathrm{Sb}, \mathrm{As})_{2} \mathrm{~S}_{11}\right]$, famatinite $\left(\mathrm{Cu}_{3} \mathrm{SbS}_{4}\right)$, proustite $\left(\mathrm{Ag}_{3} \mathrm{AsS}_{3}\right)$, and tetrahedrite. Gold occurs as $\mathrm{Au}-\mathrm{Ag}$ alloy and uytenbogaardtite $\left(\mathrm{Ag}_{3} \mathrm{AuS}_{2}\right)$. Chalcocite, native gold, stromeyerite $(\mathrm{AgCuS})$, rare covellite and mckinstryite $\left[(\mathrm{Ag}, \mathrm{Cu})_{2} \mathrm{~S}\right]$ are the latest phases, of supergene origin. Microthermometric data and the mineral association indicate the presence of a low-salinity fluid, evolving from low $f\left(\mathrm{~S}_{2}\right)$ at a temperature of about $220^{\circ} \mathrm{C}$ to higher $f\left(\mathrm{~S}_{2}\right)$ at a temperature below $200^{\circ} \mathrm{C}$. Dendritic native gold probably formed from dissolution of $\mathrm{Au}-\mathrm{Ag}$ alloy and reprecipitation of gold and stromeyerite - mckinstryite from a supergene copper-bearing fluid.
\end{abstract}

Keywords: famatinite, uytenbogaardtite, stromeyerite - mckinstryite, epithermal deposit, gold, fluid evolution, supergene enrichment, Pongkor, Indonesia.

\section{SOMMAIRE}

Le gisement d'or et d'argent de Pongkor, d'âge pliocène (2.05 $\pm 0.05 \mathrm{Ma})$, est le plus gros gisement de métaux précieux de type épithermal à faible taux de sulfuration en Indonésie. Il contient neuf veines majeures subparallèles à quartz - "adulaire" carbonate contenant une très faible proportion de sulfures. L'association de sulfures est le porteur principal d'or; elle contient surtout pyrite, chalcopyrite, sphalérite \pm galène (stade des sulfures gris + quartz). Les phases accessoires sont des sulfures et sulfosels argentifères, comme acanthite-aguilarite $\left(\mathrm{Ag}_{2} \mathrm{~S}-\mathrm{Ag}_{4} \mathrm{SSe}\right)$, polybasite-pearceïte $\left[(\mathrm{Ag}, \mathrm{Cu})_{16}(\mathrm{Sb}, \mathrm{As})_{2} \mathrm{~S}_{11}\right]$, famatinite $\left(\mathrm{Cu}_{3} \mathrm{SbS}_{4}\right)$, proustite $\left(\mathrm{Ag}_{3} \mathrm{AsS}_{3}\right)$, et tetraédrite. L'or se présente sous forme d'alliage $\mathrm{Au}-\mathrm{Ag}$ et d'uytenbogaardtite $\left(\mathrm{Ag}_{3} \mathrm{AuS} \mathrm{S}_{2}\right)$. Chalcocite, or natif, stromeyerite $(\mathrm{AgCuS})$, et de rares exemples de covellite et mckinstryite $\left[(\mathrm{Ag}, \mathrm{Cu})_{2} \mathrm{~S}\right]$ sont les phases tardives, d'origine supergène. Les données microthermométriques et l'association de minéraux indique la présence d'une phase fluide de faible salinité, dont l'évolution va de faibles fugacités de soufre, $f\left(\mathrm{~S}_{2}\right)$, à environ $220^{\circ} \mathrm{C}$ vers une fugacité accrue au-dessous de $200^{\circ} \mathrm{C}$. L'or natif dendritique serait dû à la dissolution de l'alliage $\mathrm{Au}-\mathrm{Ag}$ et reprécipitation de l'or et de stromeyerite mckinstryite à partir d'un fluide cuprifère supergène.

(Traduit par la Rédaction)

Mots-clés: famatinite, uytenbogaardtite, stromeyerite - mckinstryite, gisement épithermal, or, évolution des fluides, enrichissement supergène, Pongkor, Indonésie.

§E-mail addresses: i.wayan.warmada@tu-clausthal.de, lehmann@min.tu-clausthal.de, marolop.simandjuntak@antam.com 


\section{INTRODUCTION}

The Pongkor gold-silver deposit, located in west Java, Indonesia, was discovered in 1988 during systematic sampling of stream sediment (Basuki et al. 1994). The mine, operated by PT Aneka Tambang, has been active since 1992 and has an annual production of 3-4 t $\mathrm{Au}$ and $21-28 \mathrm{t} \mathrm{Ag}$. The currently mineable reserves are $5 \mathrm{Mt}$ at $12 \mathrm{~g} / \mathrm{t} \mathrm{Au}+137 \mathrm{~g} / \mathrm{t} \mathrm{Ag}$ with a cut-off grade of $4 \mathrm{~g} / \mathrm{t} \mathrm{Au}$. The total metal content (past production + reserves + resources) is estimated to be around $110 \mathrm{t}$ $\mathrm{Au}$. The deposit is of epithermal low-sulfidation type and has a ${ }^{40} \mathrm{Ar} /{ }^{39} \mathrm{Ar}$ age ("adularia") of $2.05 \pm 0.05 \mathrm{Ma}$ (Milési et al. 1999).

Details of the geology, hydrothermal alteration and mineralization, fluid-inclusion petrography, and lead isotope data have been reported by Basuki et al. (1994), Marcoux \& Milési (1994), Marcoux et al. (1996) and Milési et al. (1999). In the present study, we provide new information on polymetallic sulfide and sulfosalt minerals in the ore assemblage, based on ore microscopy and results of electron-microprobe analyses.

\section{Geological Setting}

The Pongkor area is part of the Neogene SundaBanda continental arc that developed along the southern margin of the Eurasian plate as a result of northward subduction of the Indian-Australian plate. Western Java hosts a number of epithermal deposits of precious metals associated with the calc-alkaline volcanism, still active in the area (Fig. 1). The Pongkor gold-silver deposit is located at the northeastern flank of the Bayah dome, $80 \mathrm{~km}$ southwest of Jakarta. This geological unit is exposed over an area of about 40 by $80 \mathrm{~km}$ and consists of shale and sandstone basement overlain by the central volcanic belt of Oligocene to Early Miocene age, composed of largely coarse-grained volcaniclastic rocks, with intercalated limestone and sandstone. Intermediate intrusive rocks were emplaced into Paleogene and Early Miocene formations (Basuki et al. 1994).

Three major volcanic units of Miocene-Pliocene age dominate the area (Milési et al. 1999). The lower unit is characterized by submarine calc-alkaline andesitic volcanic rocks grading laterally into epiclastic deposits. The middle unit is marked by more explosive subaerial dacitic volcanic rocks composed of lapilli tuffs overlain by lapilli-and-block tuffs and fine-grained pyroclastic tuffs and epiclastic rocks. The upper unit is formed mainly by andesite flows with a columnar structure.

The Pongkor deposit consists of nine major subparallel quartz - "adularia" - carbonate veins rich in manganese oxides and limonite, and very poor in sulfides. The veins, 740 to $2700 \mathrm{~m}$ long, several $\mathrm{m}$ thick, and more than $200 \mathrm{~m}$ deep, cut the three major volcanic units in a fan-like spatial distribution (Fig. 1). The economically most important veins are the Ciurug, Kubang Cicau, Ciguha and Pasir Jawa veins. The Cadas Copang,
Cimanganten, Gudang Handak, Gunung Goong and Pamoyanan vein systems were discovered more recently, during mine development. These veins are still under evaluation.

Mining started at the now-exhausted Pasir Jawa vein, which strikes $\mathrm{N} 150-177^{\circ} \mathrm{E}$ and dips $60-85^{\circ} \mathrm{W}$. The length of the 4- to 5 m-thick quartz - "adularia" - carbonate vein is $950 \mathrm{~m}$, and the metal content recovered was $1.4 \mathrm{t} \mathrm{Au}$ and $20.3 \mathrm{t} \mathrm{Ag}$. The Ciguha vein, about $500 \mathrm{~m}$ west, is still in production and consists dominantly of quartz, calcite, dolomite, kutnohorite, and rhodochrosite, the Mn minerals being partially weathered to Mn-oxide-rich pockets. The metal content is 11.1 $\mathrm{t} \mathrm{Au}$ and $158.3 \mathrm{t} \mathrm{Ag}$. The strike and dip directions of the two branches $A$ and $B$ of the vein system are $N 150^{\circ} \mathrm{E} /$ $70-85^{\circ} \mathrm{W}$ and $\mathrm{N} 160^{\circ} \mathrm{E} / 70^{\circ} \mathrm{W}$, respectively, with a total length of $1700 \mathrm{~m}$ and an average thickness of $4 \mathrm{~m}$. The Kubang Cicau vein further west is the second most important one in the district $(30.1 \mathrm{t} \mathrm{Au}$ and $313.2 \mathrm{t} \mathrm{Ag})$, with strike/dip direction of $\mathrm{N} 155^{\circ} \mathrm{E} / 75^{\circ} \mathrm{E}$, a total length of $2700 \mathrm{~m}$ and an average thickness of $3.5 \mathrm{~m}$. It consists mainly of quartz, carbonate, "adularia", illite/smectite, and montmorillonite, and has locally calcite stockworks with a chlorite selvage. The Ciurug vein consists of massive calcite, locally up to several meters in thickness with intercalated manganese carbonate and quartz. The upper part of the vein is strongly weathered and contains many pockets of manganese oxide and clay. The maximum width of the vein varies from 7 meters near the surface up to $24 \mathrm{~m}$ at depth. It contains $55.9 \mathrm{t}$ of gold and 534.6 tof silver over the total length of $2000 \mathrm{~m}$. The Gudang Handak vein consists of quartz, calcite and manganese carbonate, which is mostly weathered to manganese oxides. Its width is $2-8 \mathrm{~m}$. The metal content is $8.4 \mathrm{t} \mathrm{Au}$ and $114 \mathrm{t} \mathrm{Ag}$. The Gudang Handak vein has a strike/dip direction of $\mathrm{N}\left({ }^{\circ} \mathrm{E} / 80-85^{\circ} \mathrm{E}\right.$ and a total length of $740 \mathrm{~m}$. The Pamoyanan vein was recently explored and contains $0.5 \mathrm{t} \mathrm{Au}$ and $2 \mathrm{t} \mathrm{Ag}$. Its strike/dip is $\mathrm{N} 150^{\circ} \mathrm{S} / 78^{\circ} \mathrm{SW}$ with a thickness of 0.5 to $3.5 \mathrm{~m}$ and length of $1150 \mathrm{~m}$. The Cadas Copang, Cimanganten and Gunung Goong veins have not been explored so far.

The mineralized veins are interpreted as tension gashes in normal faults initiated by strike-slip movement along a conjugate system of faults (dextral NW-SE- and sinistral NNE-SSW-striking faults), and are located at the northern edge of a large $(8 \times 7 \mathrm{~km})$ caldera-like structure (Milési et al. 1999).

FIG. 1. a) Tectonic map of Indonesian region. b) Regional geology of west Java and the location of Pongkor and other major gold deposits (modified from Marcoux \& Milési 1994), Sujatmiko \& Santosa 1992). c) Pattern of the vein system in the Pongkor gold-silver deposit (PT Aneka Tambang). 


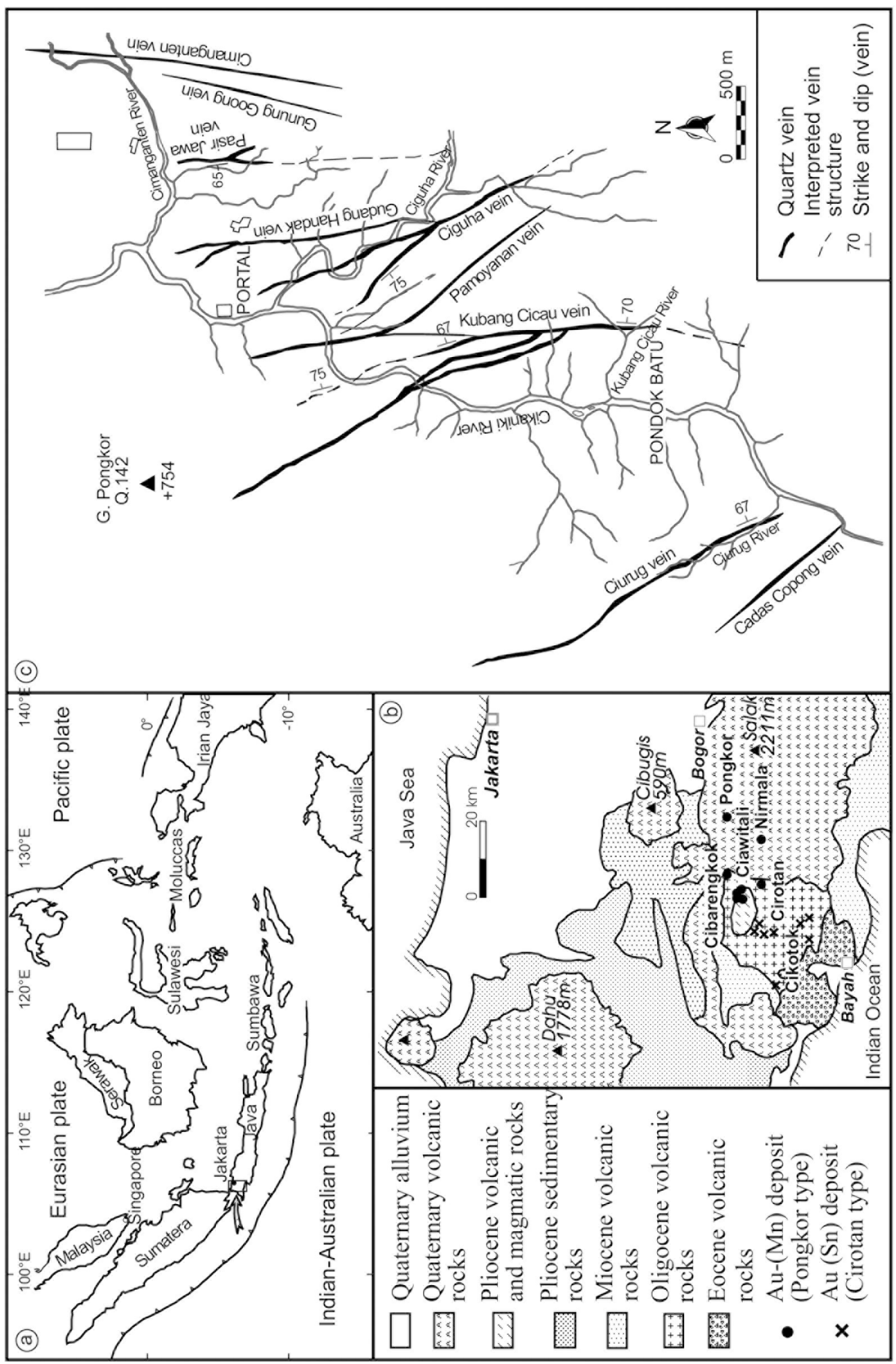




\section{Ore Mineralogy}

The veins display five stages of hydrothermal mineralization (Milési et al. 1999). These are, in chronological order:

1. Carbonate-quartz stage. This stage consists of quartz-carbonate or carbonate veinlets that locally show banding (1-60 $\mathrm{cm}$ thick). The sulfide content is very low. The carbonates are mostly calcite, rhodochrosite and dolomite. The grade of gold is low $(<1 \mathrm{~g} / \mathrm{t} \mathrm{Au})$. Disseminated pyrite occurs as wallrock impregnations in andesitic breccia and andesitic tuffs (propylitic to argillic alteration).

2. Manganese carbonate - quartz stage. The second stage is composed of alternating quartz-rhodonite and quartz-rhodochrosite bands, 3-4 cm thick. Weathering of rhodonite and rhodochrosite has formed pockets of $\mathrm{Mn}$ oxide and $\mathrm{Fe}$ oxide coatings interbedded with quartz, which locally have a high grade of gold. The non-weathered material is of low grade $(1-5 \mathrm{~g} / \mathrm{t} \mathrm{Au})$.

3. Banded quartz stage. Microcrystalline to milky quartz with a colloform structure, intercalated with bands of "adularia" and fine-grained disseminated sulfides $(<1 \mathrm{vol} . \%)$, has gold contents in the range of 5-15 $\mathrm{g} / \mathrm{t} \mathrm{Au}$. The thickness is up to $6 \mathrm{~m}$.

4. Grey sulfide - quartz stage. This main gold-bearing stage consists of grey sulfide-rich quartz breccia (hydrothermal breccia pipes), "adularia", and banded and colloform quartz with a grade $>20 \mathrm{~g} / \mathrm{t} \mathrm{Au}$. The thickness varies from less than $1 \mathrm{~mm}$ up to $1 \mathrm{~m}$.

5. Vuggy quartz stage: Euhedral quartz and calcite form the late infill of cavities. This stage is entirely barren.

The main components of the ore are pyrite, chalcopyrite, sphalerite, galena, $\mathrm{Au}-\mathrm{Ag}$ alloy and silver sulfosalts (acanthite, aguilarite, pearceite-polybasite); trace amounts of hessite were reported by Milési et al. (1999). The Au-Ag alloy, in amoeboid patches, is the most important gold-bearing mineral; it commonly occurs as inclusions in pyrite and, more rarely, in silver sulfosalts. The average gold content of the gold-silver alloy is $59 \mathrm{wt} . \%$ (range: 32 to $84 \mathrm{wt} . \% \mathrm{Au}$ ).

Our mineralogical study has focused on the highgrade gold ore; we identified some additional minerals, such as famatinite, proustite, tetrahedrite, uytenbogaardtite, chalcocite, stromeyerite, and mckinstryite, which are described below. The minerals willemite and massicot were found only in one strongly weathered sample.

\section{Samples And Analytical Technique}

The samples were collected during mine visits in mid-1999 and 2001, and were taken from stope exposures of the Kubang Cicau vein $(550,600,650$, and 690 $\mathrm{m}$ levels). Additional samples from deeper levels and non-active mine sections, i.e., Ciguha, Ciurug, and Gudang Handak veins, were collected from drill cores.
Forty samples were studied in polished sections, selected from various depth-levels and from localities with a significant amount of sulfides.

Microchemical analyses were performed with a Cameca SX-100 electron microprobe at the Institute of Mineralogy and Mineral Resources, Technical University of Clausthal. We used the following operating conditions: accelerating voltage $20 \mathrm{kV}$, beam current $20 \mathrm{nA}$, and beam diameter 1-5 $\mu \mathrm{m}$. We used the following standards: $\mathrm{ZnS}(\mathrm{Zn} K \alpha, \mathrm{S} K \alpha)$, pure $\mathrm{Ag}(\mathrm{Ag} L \alpha), \mathrm{CdS}(\mathrm{Cd} L \alpha)$, $\mathrm{InSb}(\mathrm{Sb} L \alpha)$, pure $\mathrm{Mn}(\mathrm{Mn} K \alpha), \mathrm{CuFeS}_{2}(\mathrm{Cu} K \alpha, \mathrm{Fe} K \alpha)$, pure $\mathrm{Au}(\mathrm{Au} L \alpha), \mathrm{Ag}_{2} \mathrm{Te}(\mathrm{Te} L \alpha), \mathrm{PbTe}(\mathrm{Pb} L \beta), \mathrm{GaAs}$ $(\mathrm{As} L \beta)$ and pure $\mathrm{Se}(\mathrm{Se} L \alpha)$. In all cases, we employed counting times of $20 \mathrm{~s}$, except for As and Se (24 s). The detection limits vary from $0.04(\mathrm{Fe})$ to $0.36 \mathrm{wt} . \%(\mathrm{~Pb})$.

The samples of bulk ore were analyzed by combined instrumental neutron-activation analysis (INAA) (Au, $\mathrm{Mo}, \mathrm{Na}, \mathrm{As}, \mathrm{Sb}, \mathrm{Sc}$ and $\mathrm{Se}$ ), four-acid-digestion inductively coupled plasma spectrometry (ICP) $(\mathrm{Cu}, \mathrm{Mn}, \mathrm{Zn}$, $\mathrm{Al}, \mathrm{Ca}, \mathrm{Fe}, \mathrm{K}$ and $\mathrm{Mg}$ ) and ICP - mass spectrometry (Ag, Cd, Pb, Ni, Ba, Be, Bi, Co, Cs, Ga, Li, Rb, Sr, Ta, $\mathrm{Te}$ and $\mathrm{Tl}$ ) at Actlabs, Canada. The samples were analyzed for sulfur by ICP following aqua regia digestion; the concentration of $\mathrm{Hg}$ was measured by a flow-injection mercury system (FIMS). The accuracy of these data is estimated at $10-30 \%$ according to replicate analyses and results on international standards.

\section{Ore Assemblages}

\section{Pyrite - chalcopyrite - sphalerite (galena)}

The most common assemblage of sulfide minerals in the vein system is pyrite - chalcopyrite - sphalerite. It occurs from the early stage of mineralization to, most abundantly, the grey sulfide - quartz stage and is associated with quartz and carbonate gangue.

Pyrite is generally idiomorphic and contains some inclusions of $\mathrm{Ag}$ sulfides, $\mathrm{Ag}$ sulfosalts and $\mathrm{Au}-\mathrm{Ag}$ alloy. Some euhedral grains of pyrite show concentric zoning, with a corrosion texture. In the weathered zone, pyrite is mostly altered to limonite and goethite.

Chalcopyrite is common and occurs as irregular patches (up to $0.5 \mathrm{~mm}$ ) associated with galena, sphalerite, silver sulfosalts and $\mathrm{Au}-\mathrm{Ag}$ alloy. It also occurs as submicrometric blebs in sphalerite ["diffusion-induced segregations - chalcopyrite (DIS-ccp)"; Bente \& Doering 1993, 1995] (Fig. 2b).

Galena is present in only a few samples, mostly from deeper levels in the veins. It is locally abundant in the deeper parts of the Ciguha, Ciurug and Gudang Handak veins, and is mostly associated with sphalerite, pyrite and chalcopyrite. Galena occasionally has trace contents of $\mathrm{Ag}$ or Se (up to $1.5 \mathrm{wt} . \%$ ) where intergrown with $\mathrm{Ag}$ sulfosalts. The cadmium content is $<0.1 \mathrm{wt}$. \%. In the oxidized zone, galena is altered to massicot $(\mathrm{PbO})$ (Fig. 2c). 
Sphalerite occurs as fine-grained aggregates and is characterized by white internal reflections under polarized light with crossed nicols. The Fe content of sphalerite is generally low ( $<2.0 \mathrm{wt} . \%)$, except in the DIS-ccp texture, where it contains up to 6 wt.\% Fe (Figs. 2a, b). Cadmium is mostly in the range 0.1 to $0.3 \mathrm{wt} . \%$, although some samples show higher concentrations, up to $3.4 \mathrm{wt} . \% \mathrm{Cd}$. The manganese concentration varies from $<0.1$ to $0.7 \mathrm{wt}$. $\% \mathrm{Mn}$. Another Zn-bearing mineral, willemite $\left(\mathrm{Zn}_{2} \mathrm{SiO}_{4}\right)$, was also found in one strongly weathered sample, with inclusions of $\mathrm{Au}-\mathrm{Ag}$ alloy (Fig. 2d).

\section{Au-Ag alloy - acanthite - polybasite-pearceite}

This main precious-metal assemblage is characterized by a wide variety of sulfide-sulfosalt minerals, which were deposited after the simple sulfide minerals (pyrite - chalcopyrite - sphalerite \pm galena). The mineral assemblage includes famatinite, tetrahedrite, polybasite-pearceite, acanthite-aguilarite, proustite, uytenbogaardtite, and $\mathrm{Au}-\mathrm{Ag}$ alloy. These minerals are abundant in the grey sulfide - quartz stage, and occur in isolated patches, as vug fillings, as interstitial aggregates, or as inclusions in pyrite.

The acanthite-aguilarite solid solution $\left(\mathrm{Ag}_{2} \mathrm{~S}-\right.$ $\mathrm{Ag}_{4} \mathrm{SSe}$ ) is not abundant, but typical of the Pongkor deposit. The selenium content ranges from trace Se in acanthite up to 13.5 wt.\% Se in aguilarite (Table 1).
Such high contents of selenium in acanthite are rare and have only been reported from a few epithermal systems in Japan (Shikazono 1978). There is no correlation between the vein facies and selenium content. As in other localities, the high content of Se in acanthite or other Ag-sulfosalt minerals probably reflects a relatively oxidizing environment, with a high ratio of selenium/ reduced sulfur (Simon et al. 1997). A submicrometric overgrowth of native silver on acanthite was detected during electron-microprobe analyses.

$A u-A g$ alloy occurs as patches or small aggregates as vug infill or inclusions in pyrite, sphalerite, Ag sulfides and sulfosalt minerals. The grain size is from submicrometric up to $100 \mu \mathrm{m}$. The variation of the $\mathrm{Ag}$ content of $\mathrm{Au}-\mathrm{Ag}$ alloy of each vein is given in Figure 3 . The data $(n=210)$ show a large variation between 16 and $68 \mathrm{wt} . \% \mathrm{Ag}$, with a mean of $40 \pm 6.6 \mathrm{wt} . \% \mathrm{Ag}$, confirming the earlier data of Milési et al. (1999) and Marcoux et al. (1996). The Se content is <0.12 wt.\%. Native gold occurs as a cementing phase associated with covellite, pyrite and polybasite.

Famatinite $\left(\mathrm{Cu}_{3} \mathrm{SbS}_{4}\right)$ occurs as fine-grained $(\sim 50$ $\mu \mathrm{m})$ brown aggregates rimming chalcopyrite and is associated with acanthite (Fig. 2e). It is characterized by parallel twinning with strong anisotropism. The chemical composition is given in Table 1 .

The polybasite-pearceite solid-solution series $\left[(\mathrm{Ag}, \mathrm{Cu})_{16}(\mathrm{Sb}, \mathrm{As})_{2} \mathrm{~S}_{11}\right]$ hosts most of the silver in the Pongkor deposit. This mineral occurs as interstitial infill

TABLE 1. RESULTS OF ELECTRON-MICROPROBE ANALYSES OF SULFIDE AND SULFOSALT MINERALS, PONGKOR DEPOSIT, INDONESIA

\begin{tabular}{|c|c|c|c|c|c|c|c|c|c|c|c|c|c|}
\hline \multirow[b]{2}{*}{ Sample } & \multicolumn{2}{|c|}{$\mathrm{Zn}-\mathrm{Td} \mathrm{Ag}-\mathrm{Td}$} & $\mathrm{Fm}$ & $\operatorname{Pr}$ & Smy & Mck & Te-Pol & \multicolumn{3}{|c|}{ Polybasite-pearceite } & \multicolumn{3}{|c|}{ Acanthite-aguilarite } \\
\hline & $\begin{array}{c}\mathrm{KC} \\
51 \\
1\end{array}$ & $\begin{array}{c}\mathrm{KC} \\
55 \\
2\end{array}$ & $\begin{array}{c}\mathrm{KC} \\
55 \\
3\end{array}$ & $\begin{array}{c}\text { GH } \\
92 \\
4\end{array}$ & $\begin{array}{c}\mathrm{KC} \\
551 \\
5\end{array}$ & $\begin{array}{c}\mathrm{KC} \\
551 \\
6\end{array}$ & $\begin{array}{c}\text { CGH } \\
35 \\
7\end{array}$ & $\begin{array}{c}\text { GH } \\
92 \\
8\end{array}$ & $\begin{array}{c}\mathrm{KC} \\
58 \\
9\end{array}$ & $\begin{array}{c}\mathrm{KC} \\
67 \\
10\end{array}$ & $\begin{array}{c}\text { CRG } \\
24 \\
11\end{array}$ & $\begin{array}{c}\mathrm{KC} \\
51 \\
12\end{array}$ & $\begin{array}{c}\mathrm{KC} \\
53 \\
13\end{array}$ \\
\hline $\mathrm{S}(\mathrm{w}$ & 24.15 & 23.01 & 28.58 & 18.28 & 15.54 & 12.92 & 210.59 & 15.57 & 14.48 & 13.67 & 12.64 & 6.21 & 10.22 \\
\hline $\mathrm{Ag}$ & 4.44 & 14. & 0 & 67.41 & 49.25 & 60.97 & 767.38 & 73.1 & 65 & 73.74 & 84.22 & 78.81 & 85.36 \\
\hline $\mathrm{Sb}$ & 28 & 27 . & 27.77 & n.d. & n.d. & 0.15 & $\begin{array}{l}5 \\
5.78\end{array}$ & n.d & 8 & 3.61 & n.d. & n.d. & n.d. \\
\hline $\mathrm{Cu}$ & 33.61 & 26.33 & 42.66 & 0.17 & 32.67 & 20.53 & 1.73 & 3.76 & 8. & 2.03 & 0.07 & 0.06 & n.d. \\
\hline $\mathrm{Zn}$ & $\begin{array}{r}5.85 \\
6.81\end{array}$ & $\begin{array}{r}5.66 \\
5.66\end{array}$ & n.d. & n.d. & n.d. & n.d. & n.d. & n.d. & $\begin{array}{l}0.4 \mathrm{~J} \\
\text { n.d. }\end{array}$ & n.d. & n.d. & n.d. & n.d. \\
\hline $\mathrm{Au}$ & n. & n.d & n.d. & n.d. & 2.34 & 0.85 & n.d. & n.d. & 0.11 & n.d. & 0.14 & 0.46 & n.d. \\
\hline $\mathrm{Te}$ & n.a. & n.a. & n.a. & n.a. & n.a. & n.a. & 5.54 & n.d. & n.d. & n.d. & n.d. & n.d. & n.d. \\
\hline $\mathrm{Fe}$ & 1.10 & 1.51 & 1.04 & n.d. & n.d. & n.d. & 0.16 & 0.37 & n.d. & n.d. & n.d. & n.d. & n.d. \\
\hline $\mathrm{Pb}$ & n.d. & n.d. & n.d. & n.d. & n.d. & 1.34 & n.d. & n.d. & n.d. & n.d. & n.d. & n.d. & n.d. \\
\hline As & 0.33 & 0.43 & n.d. & 13.81 & n.d. & n.d. & 1.08 & 6.47 & 1.29 & 3.78 & n.d. & n.d. & n.d. \\
\hline $\mathrm{Se}$ & n.d & n.d. & n.d. & 0.15 & 0.13 & 2.79 & 3.61 & n.d. & 1.76 & 2.75 & 2.06 & 13.81 & 4.66 \\
\hline
\end{tabular}

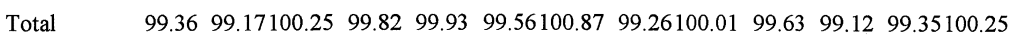

The mineral symbols are listed in Table 3; n.d.: not detected, n.a.: not analyzed.

Chemical formulae

1. $\left(\mathrm{Cu}_{9.14} \mathrm{Zn}_{1.81} \mathrm{Ag}_{0.71} \mathrm{Fe}_{0.34}\right)_{\Sigma 12}\left(\mathrm{Sb}_{4.44} \mathrm{As}_{0.08}\right)_{\Sigma 4.52} \mathrm{~S}_{13.01}$ 8. $\left(\mathrm{Ag}_{14.72} \mathrm{Cu}_{1.28} \mathrm{Fe}_{0.15}\right)_{\Sigma 16.15} \mathrm{As}_{1.87} \mathrm{~S}_{10.54}$

2. $\left(\mathrm{Cu}_{7.47} \mathrm{Ag}_{2.49} \mathrm{Zn}_{1.56} \mathrm{Fe}_{0.49}\right)_{\Sigma 12}\left(\mathrm{Sb}_{4.39} \mathrm{As}_{0.01}\right)_{\Sigma 4.40} \mathrm{~S}_{12.93}$ 9. $\left(\mathrm{Ag}_{13.14} \mathrm{Cu}_{2.86} \mathrm{Au}_{0.01}\right)_{\Sigma 16.01}\left(\mathrm{Sb}_{1.45} \mathrm{As}_{0.37}\right)_{\Sigma 1.82}\left(\mathrm{~S}_{9.73} \mathrm{Se}_{0.48}\right)_{\Sigma 10.21}$

3. $\left(\mathrm{Cu}_{3.01} \mathrm{Ag}_{0.01} \mathrm{Fe}_{0.08}\right)_{\Sigma 3.10} \mathrm{Sb}_{1.11} \mathrm{~S}_{4}$

4. $\left(\mathrm{Ag}_{3} \mathrm{Cu}_{0.01}\right)_{\Sigma 3.01} \mathrm{As}_{0.88}\left(\mathrm{~S}_{2.74} \mathrm{Se}_{0.01}\right)_{\Sigma 2.75}$

5. $\left(\mathrm{Ag}_{0.94} \mathrm{Cu}_{1.06} \mathrm{Au}_{0.02}\right)_{\Sigma 2.02} \mathrm{~S}$

10. $\left(\mathrm{Ag}_{15.29} \mathrm{Cu}_{0.71} \mathrm{Fe}_{0.02}\right)_{\Sigma 16.02}\left(\mathrm{Sb}_{0.66} \mathrm{As}_{1.13}\right)_{\Sigma 1.79}\left(\mathrm{~S}_{9.53} \mathrm{Se}_{0.78}\right)_{\Sigma 10.31}$

12. $\left(\mathrm{Ag}_{3.96} \mathrm{Au}_{0.02}\right)_{\Sigma 3.98} \mathrm{~S}_{1.05}$

6. $\left(\mathrm{Ag}_{1.27} \mathrm{Cu}_{0.73} \mathrm{Au}_{0.01} \mathrm{~Pb}_{0.01}\right)_{\Sigma 2.02}\left(\mathrm{~S}_{0.91} \mathrm{Se}_{0.08}\right)_{\Sigma 0.99} \quad 13 . \mathrm{Ag}_{2.09}\left(\mathrm{~S}_{0.84} \mathrm{Se}_{0.16}\right)_{\Sigma 1}$

7. $\left(\mathrm{Ag}_{15.33} \mathrm{Cu}_{0.67} \mathrm{Fe}_{0.07}\right)_{\Sigma 16.07}\left(\mathrm{Sb}_{1.57} \mathrm{As}_{0.35}\right)_{\Sigma 1.92}\left(\mathrm{~S}_{8.11} \mathrm{Se}_{1.12} \mathrm{Te}_{1.07}\right)_{\Sigma 10.3}$ 

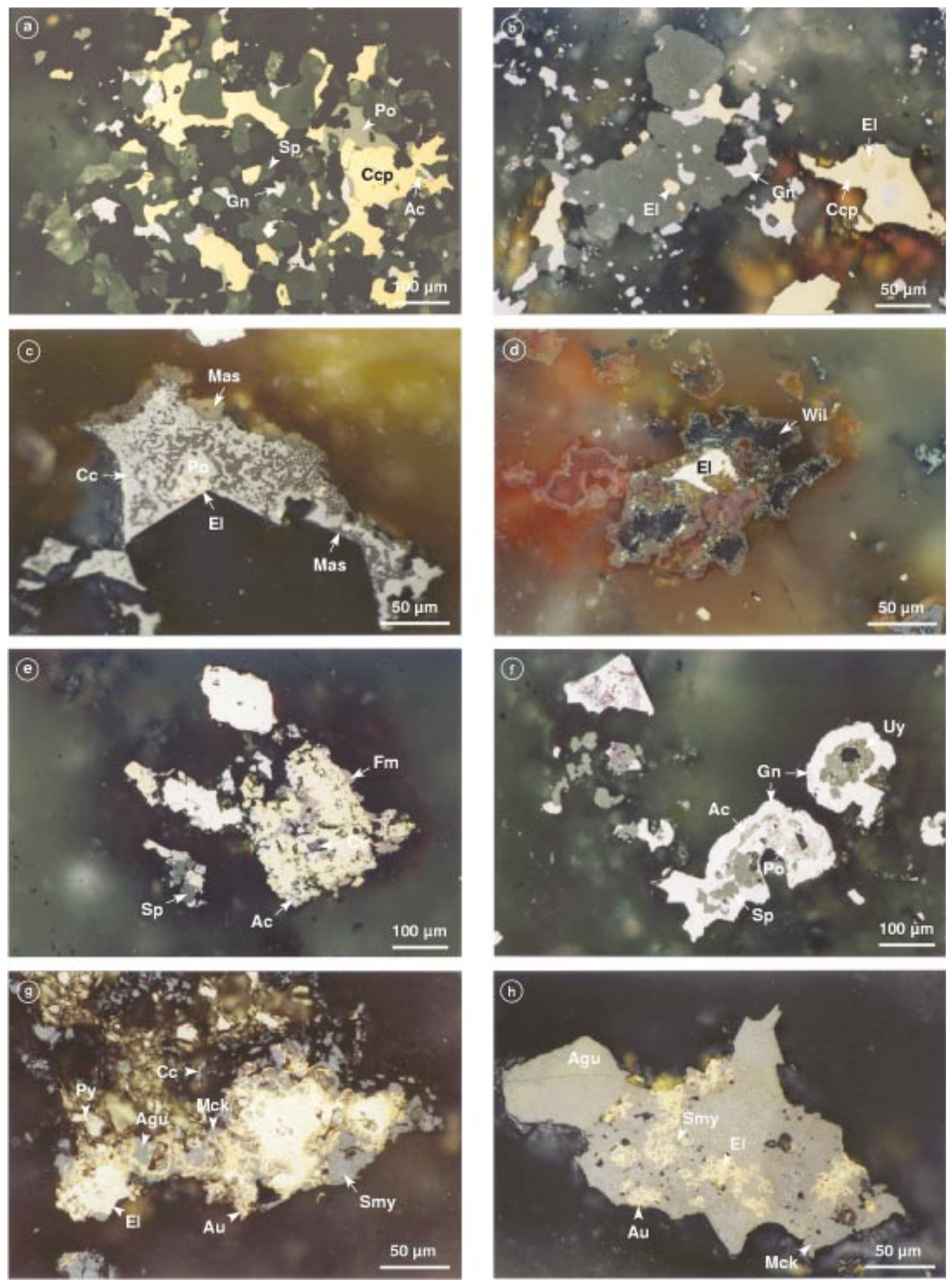


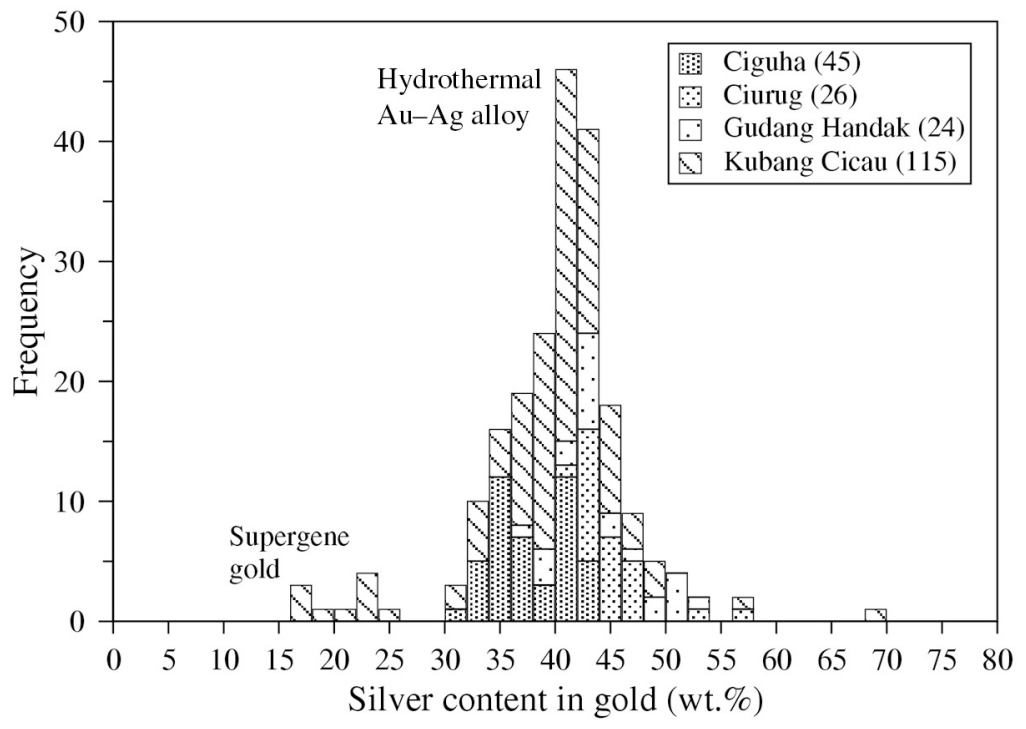

FIg. 3. Bar chart of Ag variation in $\mathrm{Au}-\mathrm{Ag}$ alloy.

among quartz or carbonate crystals or as a vug or fracture filling. The ratio of $\mathrm{Sb} /(\mathrm{As}+\mathrm{Sb})$ ranges from 0 to 1 , showing the entire range of the solid-solution series. The selenium content is variable, from 0.1 to $3.7 \mathrm{wt} . \%$ $\mathrm{Se}$, whereas the gold content ranges from 0.1 to $1.3 \mathrm{wt} . \%$ $\mathrm{Au}$. The copper content may be as high as $14.3 \mathrm{wt} . \%$ $\mathrm{Cu}$. The tellurium content of polybasite is occasionally unexpectedly high and attains $5.5 \mathrm{wt} \%$ Te. The polybasite has submicrometric inclusions of native silver (electron-microprobe analysis).

Proustite $\left(\mathrm{Ag}_{3} \mathrm{AsS}_{3}\right)$ occurs as small inclusions (about $20 \mu \mathrm{m}$ across) in acanthite (together with inclusions of arsenian polybasite) and as an intergrowth with acanthite. This ruby-colored silver mineral was only found in a single sample of high-grade ore collected from the Gudang Handak vein. The selenium content is low $(<0.10$ to 0.55 wt. $\% \mathrm{Se})$.

FIG. 2. a) Polymetallic association: low-Fe sphalerite coexists with chalcopyrite, galena, polybasite and acanthite. b) Sphalerite with DIS-ccp associated with $\mathrm{Au}-\mathrm{Ag}$ alloy and galena. c) Corroded $\mathrm{Ag}$-rich chalcocite associated with $\mathrm{Cu}$ rich polybasite, $\mathrm{Au}-\mathrm{Ag}$ alloy and massicot. d) Willemite associated with $\mathrm{Au}-\mathrm{Ag}$ alloy. e) Brown famatinite associated with chalcopyrite, covellite, acanthite, galena, sphalerite and pyrite. f) Uytenbogaardtite associated with galena, polybasite, acanthite and sphalerite. g) Oleanderleaf texture of stromeyerite associated with $\mathrm{Au}-\mathrm{Ag}$ alloy and network of gold. h) Pseudo-eutectic texture of stromeyerite and Se-rich acanthite associated with gold. Stromeyerite is partially replaced by mckinstryite. Mineral symbols are given in Table 3.
Tetrahedrite $\left[(\mathrm{Cu}, \mathrm{Ag}, \mathrm{Zn})_{12}(\mathrm{Sb}, \mathrm{As})_{4} \mathrm{~S}_{13}\right]$ was found as micrometric crystals during electron-microprobe analysis, associated with galena, chalcopyrite, sphalerite, polybasite, and uytenbogaardtite. Euhedral tetrahedrite occurs in a vuggy silica gangue. The zinc and silver content in tetrahedrite reflects the associated minerals. Zincian tetrahedrite in association with sphalerite contains up to $7 \mathrm{wt} . \% \mathrm{Zn}$ and $3.5 \mathrm{wt} \%$ Ag. Argentian tetrahedrite is closely associated with polybasite, with the Ag content being as high as $15.7 \mathrm{wt} \%$.

Uytenbogaardtite $\left(\mathrm{Ag}_{3} \mathrm{AuS}_{2}\right)$ appears in small patches (up to $50 \mu \mathrm{m}$ across) within galena (Fig. 2f), associated with acanthite, polybasite, sphalerite, chalcopyrite and covellite ( \pm argentian tetrahedrite), or occurs on the rim of $\mathrm{Au}-\mathrm{Ag}$ alloy aggregates. The chemical formula of uytenbogaardtite, calculated from results of electron-microprobe analyses, is $\mathrm{Ag}_{3} \mathrm{Au}_{0.8-1.2}$ $\mathrm{S}_{1.6-2.9}$, with $\mathrm{Ag} / \mathrm{Au}$ and $(\mathrm{Ag}+\mathrm{Au}) / \mathrm{S}$ atomic ratios of 2.6-3.5 and 1.2-2.3, respectively (Table 2, Fig. 4). The copper content varies from 0.6 to $4.7 \mathrm{wt} . \%$, whereas Se ranges from $<0.10$ to $0.76 \mathrm{wt} . \%$. The totals in Table 3 show some scatter $(100 \pm 2 \mathrm{wt} . \%)$, which is due to the small grain-size and instability under the electron beam, i.e., diffusion processes as described by Barton et al. (1978) and Rucklidge \& Stumpfl (1968).

\section{Chalcocite - acanthite - aguilarite ( \pm Au-Ag alloy or gold \pm mckinstryite \pm stromeyerite \pm covellite)}

This ore assemblage is later than the main sulfide and precious-metal assemblages and is most likely of supergene origin. 
Copper sulfide minerals in the compositional range from chalcocite $\left(\mathrm{Cu}_{2} \mathrm{~S}\right)$ to covellite $(\mathrm{CuS})$ occur in small patches associated with stromeyerite or mckinstryite, gold, $\mathrm{Au}-\mathrm{Ag}$ alloy, acanthite, aguilarite, polybasite and chalcopyrite or as independent aggregates. Chalcocite is the most common copper sulfide phase and occurs together with djurleite $\left(\mathrm{Cu}_{1.94} \mathrm{~S}\right)$, anilite $\left(\mathrm{Cu}_{7} \mathrm{~S}_{4}\right)$, digenite $\left(\mathrm{Cu}_{9} \mathrm{~S}_{5}\right)$, and metastable yarrowite $\left(\mathrm{Cu}_{9} \mathrm{~S}_{8}\right)$ and spionkopite $\left(\mathrm{Cu}_{39} \mathrm{~S}_{28}\right)$ (determined by XRD analysis). Chalcocite contains inclusions of stromeyerite and is partly replaced by dendritic covellite in association with dendritic gold.

$A u-A g$ alloy and gold occur as patches or blebs in stromeyerite and chalcocite. Dendritic gold was found

\begin{tabular}{|c|c|c|c|c|c|c|c|c|}
\hline Sample & $\begin{array}{c}\mathrm{KC} \\
51.1 \\
1\end{array}$ & $\begin{array}{c}\mathrm{KC} \\
51.2 \\
2\end{array}$ & $\begin{array}{c}\mathrm{KC} \\
51.3 \\
3\end{array}$ & $\begin{array}{c}\mathrm{KC} \\
51.4 \\
4\end{array}$ & $\begin{array}{c}\mathrm{KC} \\
55.1 \\
5\end{array}$ & $\begin{array}{c}\mathrm{KC} \\
55.2 \\
6\end{array}$ & $\begin{array}{c}\mathrm{KC} \\
58.1 \\
7\end{array}$ & $\begin{array}{c}\mathrm{KC} \\
58.2 \\
8\end{array}$ \\
\hline S (wt.\%) & 11.01 & 15.36 & 9.47 & 10.20 & 10.57 & 13.10 & 11.26 & 11.73 \\
\hline $\mathrm{Ag}$ & 53.94 & 53.98 & 54.35 & 55.98 & 51.70 & 50.64 & 57.36 & 54.01 \\
\hline $\mathrm{Cu}$ & 4.66 & 2.99 & 2.38 & 4.02 & 0.57 & 0.61 & 4.00 & 3.0 \\
\hline $\mathrm{Au}$ & 28.17 & 29.16 & 31.61 & 29.24 & 36.24 & 38.18 & 28.22 & 28.6 \\
\hline $\mathrm{Se}$ & 0.40 & 0.76 & 0.42 & 0.33 & n.d. & n.d. & 0.43 & 0.80 \\
\hline Total & 98.17 & 102.25 & 98.23 & 99.78 & 99.09 & 102.53 & 101.28 & 98.25 \\
\hline
\end{tabular}

Chemical formulae

1. $\left(\mathrm{Ag}_{2.62} \mathrm{Cu}_{0.38}\right)_{\Sigma 3} \mathrm{Au}_{0.75}\left(\mathrm{~S}_{1.80} \mathrm{Se}_{0.03}\right)_{\Sigma 1.83}$

2. $\left(\mathrm{Ag}_{2.74} \mathrm{Cu}_{0.26}\right)_{23} \mathrm{Au}_{0.81}\left(\mathrm{~S}_{2.62} \mathrm{Se}_{0.05}\right)_{\Sigma 2.67}$

3. $\left(\mathrm{Ag}_{2.79} \mathrm{Cu}_{0.21}\right)_{\Sigma 3} \mathrm{Au}_{0.89}\left(\mathrm{~S}_{1.64} \mathrm{Se}_{0.03}\right)_{\Sigma 1.67}$

4. $\left(\mathrm{Ag}_{2.67} \mathrm{Cu}_{0.33}\right)_{\Sigma 3} \mathrm{Au}_{0.76}\left(\mathrm{~S}_{1.64} \mathrm{Se}_{0.02}\right)_{\Sigma 1.66}$

5. $\left(\mathrm{Ag}_{2.94} \mathrm{Cu}_{0.06}\right)_{\Sigma 3} \mathrm{Au}_{1.13} \mathrm{~S}_{2.03}$

7. $\left(\mathrm{Ag}_{2.68} \mathrm{Cu}_{0.06}\right)_{\Sigma 3} \mathrm{Au}_{0.72}\left(\mathrm{~S}_{1.77} \mathrm{Se}_{0.03}\right)_{\Sigma 1.80}$

7. $\left(\mathrm{Ag}_{2.74} \mathrm{Cu}_{0.26}\right)_{\Sigma 3} \mathrm{Au}_{0.80}\left(\mathrm{~S}_{2.00} \mathrm{Se}_{0.06}\right)_{\Sigma 2.06}$

TABLE 3. ORE MINERALS ENCOUNTERED IN THE PONGKOR DEPOSIT, INDONESIA

\begin{tabular}{|c|c|c|}
\hline Mineral types & Chemical formulas & Symbol \\
\hline \multicolumn{3}{|c|}{ Oxide minerals } \\
\hline $\begin{array}{l}\text { Massicot } \\
\text { Willemite }\end{array}$ & $\begin{array}{l}\mathrm{PbO} \\
\mathrm{Zn}_{2} \mathrm{SiO}_{4}\end{array}$ & $\begin{array}{l}\text { Mas } \\
\text { Wil }\end{array}$ \\
\hline \multicolumn{3}{|c|}{ Major minerals } \\
\hline $\begin{array}{l}\text { Chalcopyrite } \\
\text { Au-Ag alloy } \\
\text { Pyrite } \\
\text { Sphalerite }\end{array}$ & $\begin{array}{l}\mathrm{CuFeS} \\
(\mathrm{Au}, \mathrm{Ag}) \\
\mathrm{FeS}_{2} \\
\mathrm{ZnS}\end{array}$ & $\begin{array}{l}\text { Ccp } \\
\mathrm{El} \\
\mathrm{Py} \\
\mathrm{Sp}\end{array}$ \\
\hline \multicolumn{3}{|c|}{ Minor minerals } \\
\hline $\begin{array}{l}\text { Acanthite } \\
\text { Aguilarite } \\
\text { Covellite } \\
\text { Galena } \\
\text { Polybasite } \\
\text { Pearceite }\end{array}$ & $\begin{array}{l}\mathrm{Ag}_{2} \mathrm{~S} \\
\mathrm{Ag}_{4} \mathrm{SSe} \\
\mathrm{CuS} \\
\mathrm{PbS} \\
(\mathrm{Ag}, \mathrm{Cu})_{16} \mathrm{Sb}_{2} \mathrm{~S}_{11} \\
(\mathrm{Ag}, \mathrm{Cu})_{16} \mathrm{As}_{2} \mathrm{~S}_{11}\end{array}$ & $\begin{array}{l}\mathrm{Ac} \\
\mathrm{Agu} \\
\mathrm{Cv} \\
\mathrm{Gn} \\
\mathrm{Pol} \\
\mathrm{Pe}\end{array}$ \\
\hline \multicolumn{3}{|c|}{ Trace minerals } \\
\hline $\begin{array}{l}\text { Chalcocite } \\
\text { Famatinite } \\
\text { Hessite* } \\
\text { Mckinstryite } \\
\text { Native gold } \\
\text { Native silver } \\
\text { Proustite } \\
\text { Stromeyerite } \\
\text { Tetrahedrite } \\
\text { Uytenbogaardtite }\end{array}$ & $\begin{array}{l}\mathrm{Cu}_{2} \mathrm{~S} \\
\mathrm{Cu}_{3} \mathrm{SbS}_{4} \\
\mathrm{Ag}_{2} \mathrm{Te} \\
(\mathrm{Ag}, \mathrm{Cu})_{2} \mathrm{~S} \\
\mathrm{Au} \\
\mathrm{Ag} \\
\mathrm{Ag}_{3} \mathrm{AsS}_{3} \\
\mathrm{AgCuS} \\
(\mathrm{Cu}, \mathrm{Ag}, \mathrm{Zn}, \mathrm{Fe})_{12} \mathrm{Sb}_{4} \mathrm{~S}_{13} \\
\mathrm{Ag}_{3} \mathrm{AuS}{ }_{2}\end{array}$ & $\begin{array}{l}\mathrm{Cc} \\
\mathrm{Fm} \\
\mathrm{Hs} \\
\mathrm{Mck} \\
\mathrm{Au} \\
\mathrm{Ag} \\
\mathrm{Pr} \\
\mathrm{Smy} \\
\mathrm{Td} \\
\mathrm{Uy}\end{array}$ \\
\hline
\end{tabular}

* Milési èt al. (1999). in association with acanthite-aguilarite, $\mathrm{Au}-\mathrm{Ag}$ alloy, stromeyerite or mckinstryite and chalcocite-associated minerals, occurring as a rim on $\mathrm{Au}-\mathrm{Ag}$ alloy or as veinlets in chalcocite (Figs. 2g, h). The gold content in $\mathrm{Au}-$ $\mathrm{Ag}$ alloy or native gold varies from 60 to $86 \mathrm{wt} . \% \mathrm{Au}$. Gold with $>80$ wt.\% Au invariably is associated with stromeyerite, aguilarite, and mckinstryite.

Stromeyerite-mckinstryite $\left[(\mathrm{Ag}, \mathrm{Cu})_{2} \mathrm{~S}\right]$ occurs as intergrowth aggregates with aguilarite in an oleanderleaf texture (Schwartz 1935) (Fig. 2g) or pseudo-eutectic texture (Fig. 2h). Stromeyerite ( $\mathrm{AgCuS}$ ) is much more abundant than mckinstryite, and occurs together with gold, $\mathrm{Au}-\mathrm{Ag}$ alloy, chalcocite, and polybasite. The gold content of stromeyerite is variable, between $<0.1$ to $4 \mathrm{wt} . \%$. Mckinstryite, $(\mathrm{Ag}, \mathrm{Cu})_{2} \mathrm{~S}$, is rare and found associated with stromeyerite, gold, $\mathrm{Au}-\mathrm{Ag}$ alloy, and aguilarite. The composition is given in Table 1 and Figure 5.

\section{BulK-Ore Composition}

Results of multi-element analyses for selected highgrade ore samples are given in Table 4. Variation diagrams for pairs of trace elements in bulk-ore samples are given in Figure 6.

Positive correlation trends for the element groups $\mathrm{Ag}-\mathrm{Au}-\mathrm{Se}$ and $\mathrm{Cu}-\mathrm{Pb}-\mathrm{Zn}-\mathrm{Cd}$ (Fig. 6) point to a mineralogical control of element distribution. The $\mathrm{Ag}-\mathrm{Au}-$ $\mathrm{Se}$ group relates to selenide-rich $\mathrm{Ag}$ sulfide and $\mathrm{Ag}$ sulfosalt minerals, whereas the $\mathrm{Cu}-\mathrm{Pb}-\mathrm{Zn}-\mathrm{Cd}$ group relates to base-metal sulfides, such as chalcopyrite, galena, sphalerite, tetrahedrite and famatinite. The As-Sb plot shows a scattered distribution, which indicates that the solid solution of As-Sb-bearing minerals is not the dominant control for these elements.

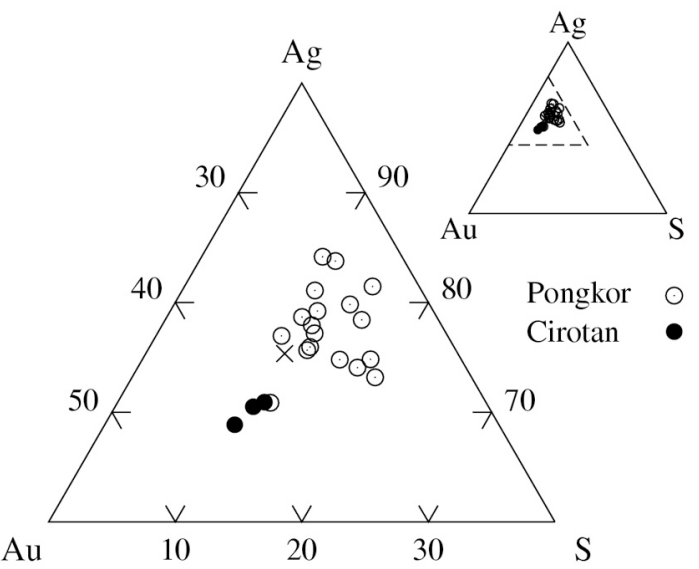

FIG. 4. Composition of uytenbogaardtite in the system Ag$\mathrm{Au}-\mathrm{S}$ (wt.\%). Cross locates the stoichiometric composition of $\mathrm{Ag}_{3} \mathrm{AuS}_{2}$. 
The As-Au plot also shows a weak positive correlation, with relatively little variation in As abundance (10$200 \mathrm{ppm} \mathrm{As}$ ) compared to nearly four orders of magnitude for Au. The abundance of mercury is very low $(<0.2 \mathrm{ppm} \mathrm{Hg})$ and gives a scattered distribution with silver, suggesting the absence of a direct mineralogical control by tetrahedrite. The correlation trends confirm the paragenetic observations from ore microscopy, i.e., a chemical and mineralogical trend from the early base-metal stage $(\mathrm{Cu}-\mathrm{Pb}-\mathrm{Zn}-\mathrm{Cd}$ mineral paragenesis) to the late precious-metal stage $[\mathrm{Ag}-\mathrm{Au}-(\mathrm{Se}) \mathrm{min}-$ eral paragenesis].

Several correlation trends tend toward the bulk composition of the bulk continental crust, or intersect it. The interelement correlation-trends for $\mathrm{Ag}-\mathrm{Au}-\mathrm{Se}$ suggest a similar process of enrichment for these elements (2-6 orders of magnitude compared to bulk continental crust), with gold the most enriched over bulk continental crust. The position of the bulk continental crust on the extrapolated correlation-trends suggests leaching of these ele- ments from the continental crust with a similar degree of efficiency. The base metals are much less enriched over bulk continental crust (from no enrichment up to three orders of magnitude) and indicate a much less efficient process of leaching. The low abundance of mercury in the system (10-200 ppb) could be a result of the high mobility of mercury.

The continental crust as a source of the metals is also indicated by lead isotope ratios on volcanic bulk-rock samples $\left({ }^{207} \mathrm{~Pb} / 204 \mathrm{~Pb} \approx 15.69\right)$ (Milési et al. 1999), which exclude a significant input from the mantle. The lead isotope signatures of the epithermal gold-silver deposits and Pliocene magmatic rocks demonstrate the existence of an underlying continental basement, which is also indicated by the presence of fragments of Late Paleozoic fossiliferous sedimentary rocks in the blocks of lapilli tuff (Milési et al. 1999).

Values of the silver:gold ratio from assay data (ore blocks) are shown in Figure 7. A large part of the Ciurug vein and minor upper parts of the Ciguha $\mathrm{A}$ and $\mathrm{B}$, Pasiv

TABLE 4. COMPOSITION OF SELECTED UNCOMMON HIGH-GRADE ORE SAMPLES FROM THE PONGKOR EPITHERMAL GOLD-SIL VER DEPOSIT, INDONESIA

\begin{tabular}{|c|c|c|c|c|c|c|c|c|c|c|c|}
\hline Sample & $\mathrm{CGH}$ & $\mathrm{CGH}$ & $\mathrm{CGH}$ & $\mathrm{CGH}$ & CRG & CRG & $\mathrm{GH}$ & $\mathrm{KC}$ & $\mathrm{KC}$ & $\mathrm{KC}$ & $\mathrm{KC}$ \\
\hline \multicolumn{2}{|c|}{-29} & -35 & -41 & -47 & -24 & -108 & -92 & -51 & -55 & -58 & -59 \\
\hline \multicolumn{2}{|c|}{ Depth (m) 89} & 83 & 122 & 114 & 200 & 120 & 10 & 50 & 100 & 100 & 100 \\
\hline \multicolumn{2}{|c|}{$\begin{array}{l}\text { Stage of } \\
\text { mineral- } 1-2 \\
\text { ization }\end{array}$} & $3-4$ & 3 & 3 & $4-5$ & 2,4 & 4 & $3-4$ & $3-4$ & $3-4$ & 4 \\
\hline $\mathrm{Li}(\mathrm{ppm}$ & 32.1 & 106 & 105 & 51.0 & 88.5 & 86.4 & 121 & 113 & 27.1 & 77.1 & 52.4 \\
\hline $\mathrm{Be}$ & 1.3 & 0.6 & 1.9 & 0.7 & 0.3 & 0.4 & 0.6 & 0.4 & 0.5 & 1.2 & 2.9 \\
\hline $\mathrm{Na}$ & 300 & 400 & 300 & 400 & 500 & 400 & 800 & 500 & 500 & 400 & 900 \\
\hline $\mathrm{Mg}$ & 2000 & 2200 & 1300 & 1200 & 5000 & 23100 & $6400 \quad 1$ & 15400 & 500 & 2100 & 7800 \\
\hline $\mathrm{Al}$ & 5900 & 15700 & 5800 & $3400 \quad 1$ & 10400 & 11200 & 127002 & 28000 & 20900 & 26200 & 39000 \\
\hline $\mathrm{S}$ & $<10$ & 70 & 50 & 2200 & 3210 & 98502 & 25690 & 19520 & 4910 & 4480 & 3510 \\
\hline $\mathrm{K}$ & 1000 & 13700 & 800 & 300 & 8800 & 300 & 8400 & 24400 & 26100 & 30200 & 45000 \\
\hline $\mathrm{Ca}$ & 236100 & 3100 & 17100 & 210011 & 16200 & 72200 & 3900 & 1400 & 400 & 14700 & 8000 \\
\hline Sc & 0.1 & 0.3 & 1.3 & 0.6 & 0.1 & 0.1 & 1.6 & 0.4 & 0.1 & 0.1 & 0.2 \\
\hline $\mathrm{Mn}$ & 25553 & 2729 & 963 & 1194 & 1039 & 1738 & 11448 & 5248 & 259 & 747 & 1421 \\
\hline $\mathrm{Fe}$ & 2600 & 3700 & 7600 & 4200 & 3600 & 18000 & 9700 & 13100 & 4500 & 4200 & $\begin{array}{l}1421 \\
5500\end{array}$ \\
\hline $\mathrm{Co}$ & 0.4 & 0.4 & 0.7 & 0.9 & 0.3 & 0.8 & 0.4 & 0.6 & 0.3 & 0.4 & 0.2 \\
\hline $\mathrm{Ni}$ & 6.4 & 2.4 & 2.3 & 1.5 & 2.1 & $\begin{array}{l}0.0 \\
1.9\end{array}$ & 3.4 & 2.1 & 2.1 & $\begin{array}{l}0.4 \\
2.3\end{array}$ & $\begin{array}{l}0.2 \\
2.9\end{array}$ \\
\hline $\mathrm{Cu}$ & 7.1 & 7.1 & 10.9 & 302 & 604 & 439 & 541 & 9580 & $1370^{2.1}$ & 167 & 97.7 \\
\hline $\mathrm{Zn}$ & 8.79 & 23.7 & 57.4 & 1217 & 1510 & $782 \quad 2$ & 29448 & 8666 & 795 & 326 & 153 \\
\hline $\mathrm{Ga}$ & 3.4 & 1.9 & 1.7 & 4.7 & 1.6 & 6.5 & 2.6 & 8.4 & 2.1 & 6.8 & 9.9 \\
\hline As & 10.2 & 39.2 & 98.3 & 62.6 & 22.9 & 36.6 & 185 & 58.9 & 46.1 & 53.7 & 46.3 \\
\hline $\mathrm{Se}$ & 14.5 & 12.0 & $<0.1$ & 8.28 & 23.6 & 52.0 & 777 & 181 & 199 & 145 & 44.3 \\
\hline $\mathrm{Rb}$ & 4.6 & 65.9 & 5.7 & 2.5 & 48.5 & 3.2 & 44.8 & 129 & 142 & 178 & 305 \\
\hline $\mathrm{Sr}$ & 123 & 59.3 & 33.9 & 9.8 & 80.0 & 39.8 & 30.4 & 15.4 & 17.2 & 52.2 & 79.3 \\
\hline Mo & 4 & $<1$ & 1 & $<1$ & 3 & 4 & 3 & 2 & $<1$ & 2 & 1 \\
\hline $\mathrm{Ag}$ & 282 & 231 & 8 & 32 & 1380 & 1680 & 10800 & 2740 & 2690 & 2730 & 835 \\
\hline $\mathrm{Cd}$ & $<0.1$ & $<0.1$ & 0.1 & 3.9 & 32.1 & 10.7 & 107 & 101 & 5.3 & 3.2 & 0.5 \\
\hline $\mathrm{Sb}$ & 12.4 & 12.6 & 14.7 & 71.8 & 34.1 & 8 & 39.1 & 125 & 146 & 156 & 83.8 \\
\hline $\mathrm{Te}$ & $<0.1$ & 0.5 & $<0.1$ & 2.7 & $<0.1$ & $<0.1$ & 0.9 & 3.1 & 0.2 & 0.2 & $<0.1$ \\
\hline $\mathrm{Cs}$ & 1.99 & 3.05 & 1.98 & 1.49 & 1.37 & 3.68 & 1.38 & 2.17 & 3.44 & 3.36 & 5.37 \\
\hline $\mathrm{Ba}$ & 6.80 & 199 & 27.3 & 6.33 & 92.4 & 5.75 & 5146 & 97.9 & 172 & 343 & 357 \\
\hline $\mathrm{La}$ & 1.3 & 1.0 & 1.1 & 1.0 & 1.2 & $<0.5$ & 2.6 & 2.5 & 1.0 & 0.7 & 1.0 \\
\hline $\mathrm{Au}$ & 3.32 & 65.3 & 0.25 & 1.62 & 27.0 & 53.0 & 416 & 711 & 225 & 133 & 18.5 \\
\hline $\mathrm{Hg}^{*}$ & 45 & 93 & 214 & 158 & 18 & 53 & 95 & 123 & 19 & 69 & 38 \\
\hline $\mathrm{Tl}$ & $<0.05$ & 1.99 & 0.11 & 0.1 & 0.89 & $<0.05$ & 1.03 & 1.98 & 1.4 & 5.03 & 8.2 \\
\hline $\mathrm{Pb}$ & 7.6 & 10.2 & 18.3 & 2010 & 769.3 & 502 & 92001 & 10100 & 438 & 276 & 36.8 \\
\hline $\mathrm{Bi}$ & 0.06 & 0.05 & 0.14 & 0.11 & 0.09 & 0.09 & 0.14 & 0.14 & 0.1 & 0.09 & 0.08 \\
\hline $\mathrm{Ag} / \mathrm{Au}$ & 85 & 3.5 & 32 & 20 & 51 & 32 & 26 & 3.9 & 12 & 21 & 45 \\
\hline
\end{tabular}

* in ppb; $\mathrm{U}<0.1 \mathrm{ppm}, \mathrm{W}<1 \mathrm{ppm}, 1:$ quartz - carbonate stage, 2: manganese carbonate - quartz stage,

3: banded-quartz stage, 4: gray sulfide - quartz stage, 5: vuggy quartz. 
Jawa and Kubang Cicau vein systems have Ag/Au values of less than 10. The Ag/Au values correlate negatively with $\mathrm{Au}$, i.e., the vein portions with low $\mathrm{Ag} / \mathrm{Au}$ values tend to have a higher grade of gold. This is likely to reflect near-surface weathering and oxidation (which in the Ciurug and Kubang Cicau veins persist down to the lowest levels) and supergene enrichment of gold.

\section{Conditions of Deposition}

There are several independent ways to estimate the temperature of ore formation, i.e., microthermometry, mineral chemistry (sphalerite - Au-Ag alloy), quartz and "adularia" textures.

A microthermometric study of carbonate- and quartz-hosted fluid inclusions (34 samples) was performed on ore samples from different levels and veins. The primary fluid inclusions are low-salinity, aqueous, and two-phase: liquid + vapor, with $\mathrm{V} /(\mathrm{L}+\mathrm{V})$ values of 15 to $30 \%$ (optical observation) (Fig. 8). High- $\mathrm{T}_{\mathrm{h}}$ (temperature of homogenization from vapor to liquid) inclusions, which have $\mathrm{V} /(\mathrm{L}+\mathrm{V})$ values of about $40-60 \%$, are also noted. These inclusions are found mostly close to microfractures in quartz crystals, and could be due to leakage. They were not considered further. However, Milési et al. (1999) have also reported a wide range of $\mathrm{V} /(\mathrm{L}+\mathrm{V})$ values of fluid inclusions $(10-80 \%)$ in quartz, which they interpreted as evidence of boiling. A summary of the homogenization and melting temperatures of the carbonate- and quartz-hosted fluid inclusions is given in Table 5. Widespread textural evidence of replacement of calcite by quartz indicates that calcite was largely deposited earlier than quartz. On the basis of the replacement texture of calcite, the carbonate-hosted fluid inclusions are considered to record the early fluid, which has a $\mathrm{T}_{\mathrm{h}}$ of $171-249^{\circ} \mathrm{C}$ (mean of $205 \pm 15^{\circ} \mathrm{C}, n=$ 250). Gold mineralization is connected with silicification, as seen from the association of gold-bearing minerals with quartz and "adularia". Therefore, the ore stage is characterized by a $\mathrm{T}_{\mathrm{h}}$ of quartz of $180-287^{\circ} \mathrm{C}$ (mean of $220 \pm 21^{\circ} \mathrm{C}, n=92$ ). Melting temperatures of both carbonate- and quartz-hosted fluid inclusions range

\begin{tabular}{|c|c|c|c|}
\hline & Mean $\pm 1 \sigma$ & $n$ & Range \\
\hline \multicolumn{4}{|c|}{ Homogenization temperature $\left(\mathrm{T}_{\mathrm{h}},{ }^{\circ} \mathrm{C}\right)$} \\
\hline $\begin{array}{l}\text { Carbonate } \\
\text { Quartz }\end{array}$ & $\begin{array}{l}205 \pm 15 \\
220 \pm 21\end{array}$ & $\begin{array}{r}250 \\
92\end{array}$ & $\begin{array}{l}171 \text { to } 249 \\
180 \text { to } 287\end{array}$ \\
\hline \multicolumn{4}{|c|}{ Temperature of first melting $\left(\mathrm{T}_{\mathrm{m}},{ }^{\circ} \mathrm{C}\right)$} \\
\hline $\begin{array}{l}\text { Carbonate } \\
\text { Quartz }\end{array}$ & $\begin{array}{l}-0.3 \pm 0.3 \\
-0.6 \pm 0.6\end{array}$ & $\begin{array}{r}234 \\
83\end{array}$ & $\begin{array}{l}-2 \text { to } 0.4 \\
-3 \text { to } 0.0\end{array}$ \\
\hline \multicolumn{4}{|c|}{ Salinity (wt.\% $\mathrm{NaCl}$ equivalent) } \\
\hline $\begin{array}{l}\text { Carbonate } \\
\text { Quartz }\end{array}$ & $\begin{array}{l}0.5 \pm 0.6 \\
1.0 \pm 1.0\end{array}$ & $\begin{array}{r}234 \\
83\end{array}$ & $\begin{array}{l}0 \text { to } 3.4 \\
0 \text { to } 5.0\end{array}$ \\
\hline
\end{tabular}

mostly in between 0 and $-1^{\circ} \mathrm{C}$, indicating a low-salinity fluid with less than 1 wt. $\% \mathrm{NaCl}$ eq., i.e., meteoric water.

Micro-analytical data on the composition of $\mathrm{Au}-\mathrm{Ag}$ alloy coexisting with sphalerite - acanthite - pyrite were used to estimate the temperature of mineral formation (Shikazono 1985, Gammons \& Williams-Jones 1995). About twenty points in several polished sections gave calculated equilibrium temperatures of $220-320^{\circ} \mathrm{C}$ (mean of $258 \pm 29^{\circ} \mathrm{C}, n=23$ ). The presence of selenium in acanthite was not considered during the estimation of temperature, but could have an influence on $\mathrm{S}_{2}$ fugacity.

Quartz textures such as colloform and crustiform banded quartz indicate a silica gel precursor and mineral formation at $<220^{\circ} \mathrm{C}$ (Dong \& Morrison 1995). The presence of rhombs of "adularia" in the bonanza ore also suggests formation temperatures of $<220^{\circ} \mathrm{C}$, as well as boiling (Dong \& Morrison 1995). Evidence of boiling was not observed with certainty in the fluid inclusions. However, the presence of "adularia" and rhodochrosite is commonly considered diagnostic of boiling (Plumlee 1994). Given the mineralogical evidence of boiling, no pressure corrections are required for the homogenization temperatures. Otherwise, the pressure correction would be on the order of $10-20^{\circ} \mathrm{C}$, taking into account the young age of the deposit and an erosion rate of 0.1 $\mathrm{mm} / \mathrm{a}$, typical of Cenozoic island arcs (Hedenquist et al. 2000).

The iron content of sphalerite (without the DIS texture) coexisting with iron sulfides is related to $f\left(\mathrm{~S}_{2}\right)$ and temperature (Barton \& Toulmin 1966). The iron content varies between 0.1 and 2.4 mole $\%$ FeS in sphalerite $(n=15)$ associated with $\mathrm{Au}-\mathrm{Ag}$ alloy - acanthite,

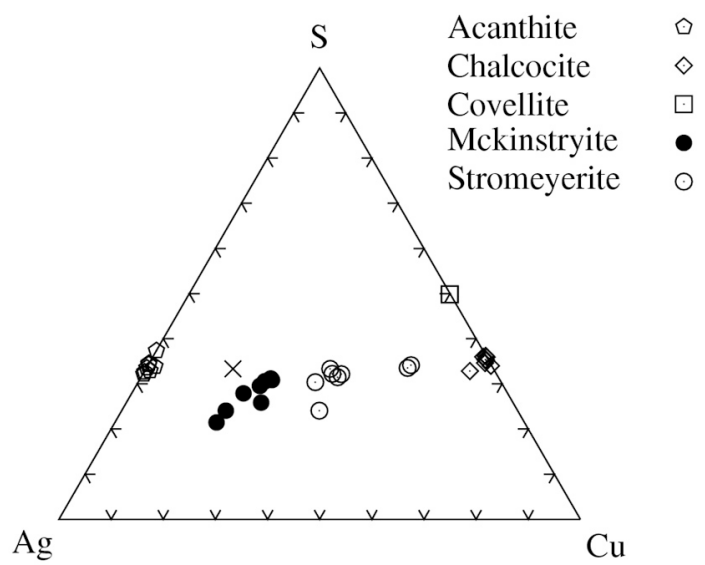

FIG. 5. Composition of $\mathrm{Cu}-\mathrm{Ag}-\mathrm{S}$-bearing phases (at.\%). Cross locates the stoichiometric composition of $\mathrm{Ag}_{3} \mathrm{CuS}_{2}$. 

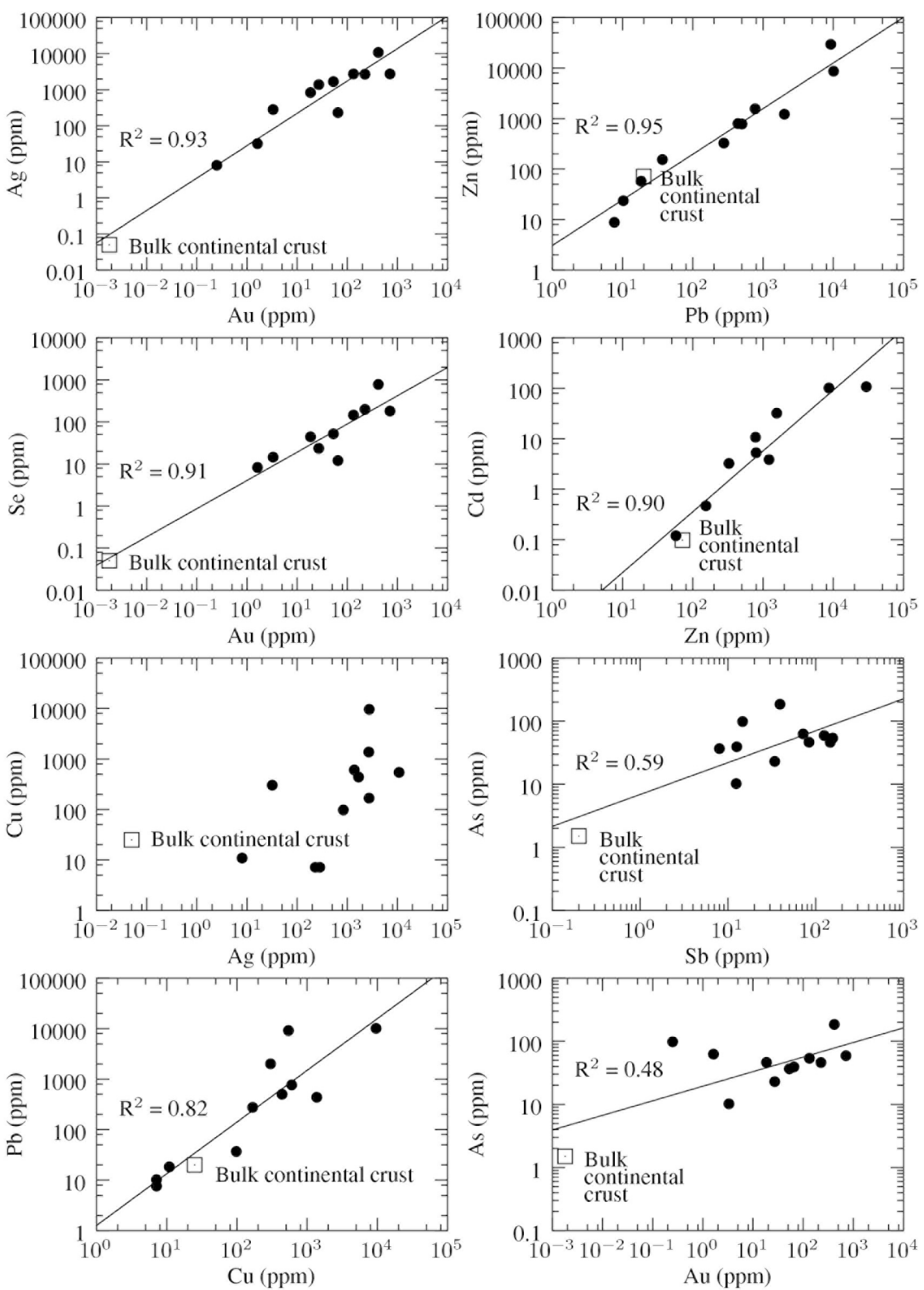

FIG. 6. Variation plots of selected trace-element pairs in bulk-ore samples. Average of continental crust from Taylor \& McLennan (1995). Some diagrams show several correlation trends, which tend toward the bulk composition of the continental crust. The base metals are much less enriched over bulk continental crust (from no enrichment up to three orders of magnitude) and indicate a much less efficient process of leaching. 

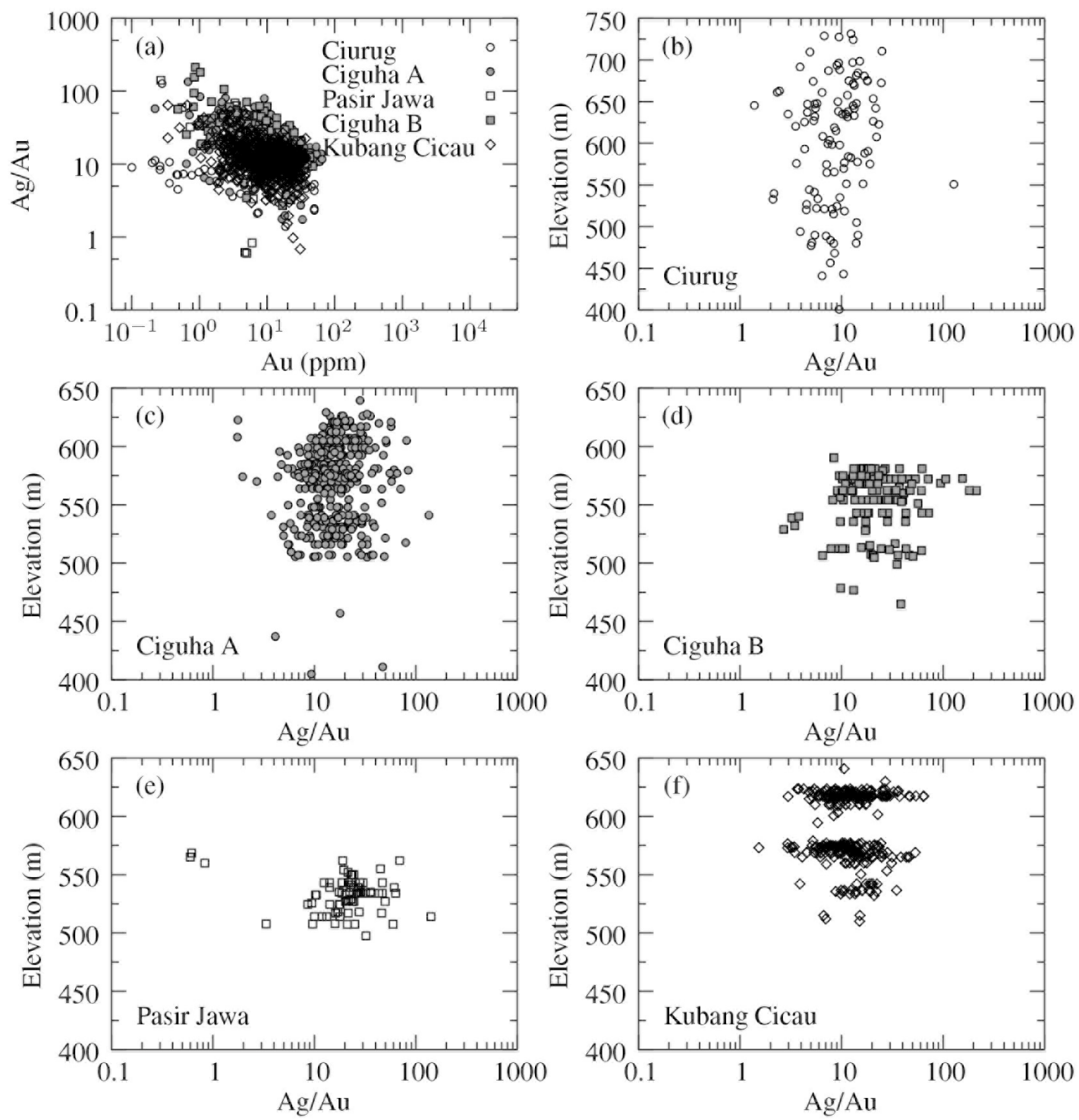

FIG. 7. Variation diagram of $\mathrm{Ag} / \mathrm{Au}$ values versus elevation in selected systems of veins. a) $\mathrm{Au}$ versus $\mathrm{Ag} / \mathrm{Au}$ in the veins. b) Ciurug vein. c). Ciguha A vein. d) Ciguha B vein. e) Pasir Jawa vein. f) Kubang Cicau vein. Source of data: PT Aneka Tambang.

and 0.1 to 3.5 mole $\%(n=12)$ in association with galena.

Figure 9 locates the ore fluid in terms of temperature and sulfur fugacity. Pyrite is a stable mineral throughout the depositional sequence. The variable iron content in sphalerite indicates a wide range in sulfur fugacities. A maximum fugacity of sulfur of $10^{-15} \mathrm{can}$ be derived from the high-Fe sphalerite, whereas a minimum fugacity of sulfur in the range $10^{-12}$ to $10^{-8}$ is in- dicated by the presence of low-Fe sphalerite and uytenbogaardtite, respectively (Barton et al. 1978).

The $f\left(\mathrm{O}_{2}\right)$-pH diagram (Fig. 10) was constructed for a temperature of $200^{\circ} \mathrm{C}$. The thermodynamic data needed to calculate the distribution of species are mainly from Johnson et al. (1992). The thermodynamic data in the form of the equilibrium constant for $\mathrm{Au}(\mathrm{HS})_{2}{ }^{-}$are derived from Benning \& Seward (1996). Isomole fraction lines for $\mathrm{FeS}$ in sphalerite were calculated from data 

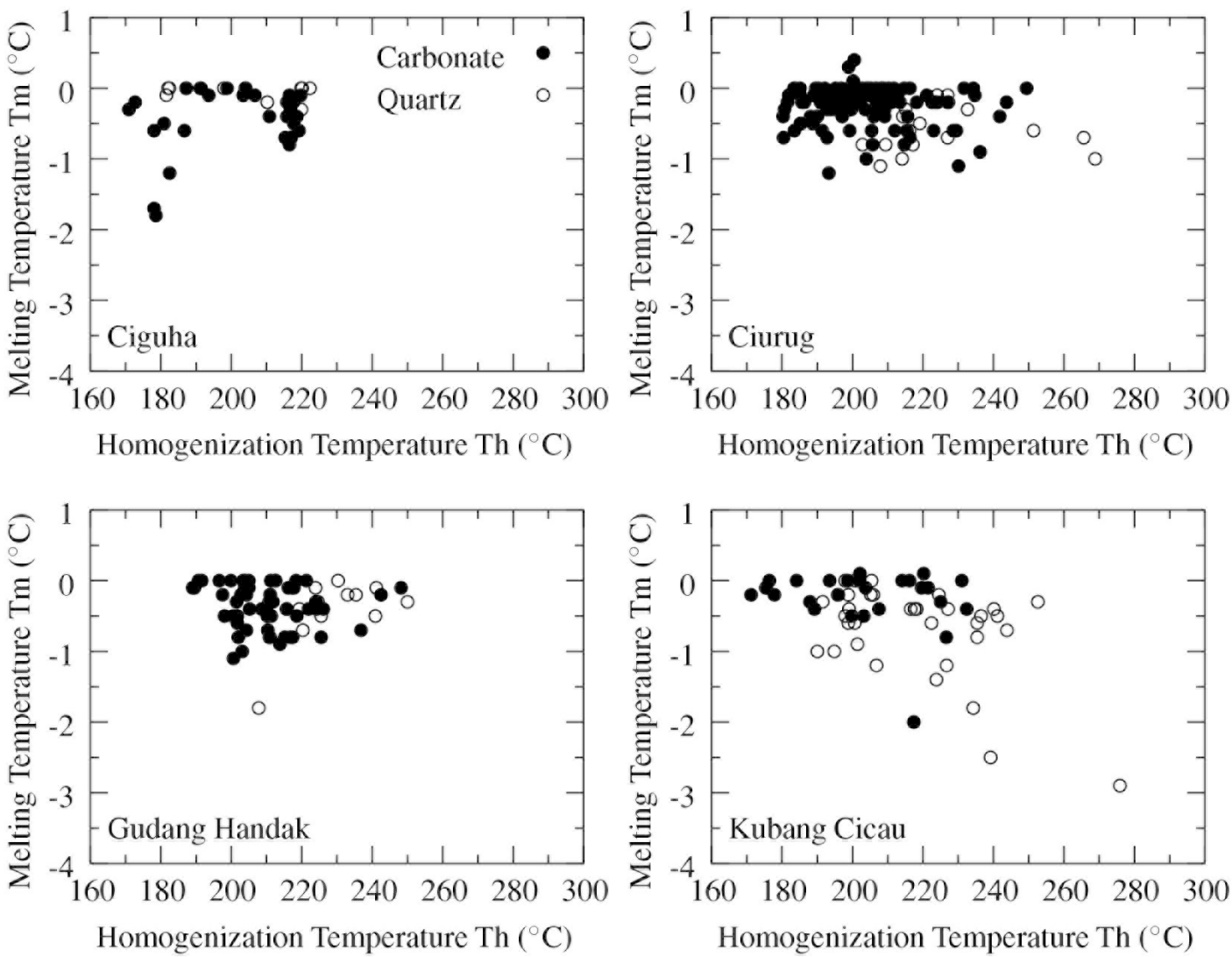

FIG. 8. Scatter plot of homogenization temperature $\left(\mathrm{T}_{h}\right)$ versus melting temperature $\left(\mathrm{T}_{\mathrm{m}}\right)$.

on the sphalerite - pyrite - pyrrhotite equilibrium by Scott \& Barnes (1971). The boundaries of the diagram were calculated using the procedures of Wood (1998). The total dissolved sulfur is assumed to be $5 \cdot 10^{-3}$ mole/ $\mathrm{kg} \mathrm{H}_{2} \mathrm{O}$ on the basis of the results of chemical analyses of hot springs associated with epithermal base-metal deposits, which are commonly in the range of $10^{-2}$ to $10^{-3}$ mole $/ \mathrm{kg} \mathrm{H}_{2} \mathrm{O}$ (Browne \& Ellis 1970 , Mohan \& Finlayson 1972).

On the basis of the iron content of sphalerite, mineral stability relations, solubility of $\mathrm{Au}(\mathrm{HS})_{2}{ }^{-}$, and "adularia" stability, the possible $f\left(\mathrm{O}_{2}\right)-\mathrm{pH}$ range for the Pongkor Au-Ag mineralization was estimated (Fig. 10). The composition of the fluid is favorable for a maximum transport of gold of up to $3000 \mathrm{ppb} \mathrm{Au}$ (see shaded region in Fig. 10). The primary hydrothermal ore was overprinted by weathering. Locally high grades of gold of $16 \mathrm{~g} / \mathrm{t}$ or more tend to be concentrated in the shallow part of the veins, with low Ag/Au values, less than 10 (Fig. 7a). The lower Ag/Au values in these portions of the vein systems indicate supergene enrichment of gold.

\section{Discussion And Conclusions}

The Pongkor deposit has a remarkably low content of sulfide minerals, and the overall base-metal content of the ore is $<100 \mathrm{ppm}$, although high-grade ore sections locally can have several percent of copper and zinc. The assemblage of gangue minerals quartz - carbonate - "adularia" defines Pongkor as a low-sulfide lowsulfidation type of deposit. The ore system developed in a shallow epithermal environment characterized by low-salinity (meteoric) water at a temperature around $220^{\circ} \mathrm{C}$.

The acanthite-aguilarite and polybasite-pearceite solid-solution series are typical of all vein systems at Pongkor. The sporadic Te content in polybasite is attributed to the existence of fine-grained intergrowths with minerals such as hessite, as reported by Milési et al. (1999). Selenium is positively correlated with gold and silver in bulk samples of ore. The Au-Ag-Se correlation suggests a causal relationship for these three elements. The high selenium content indicates a relatively 


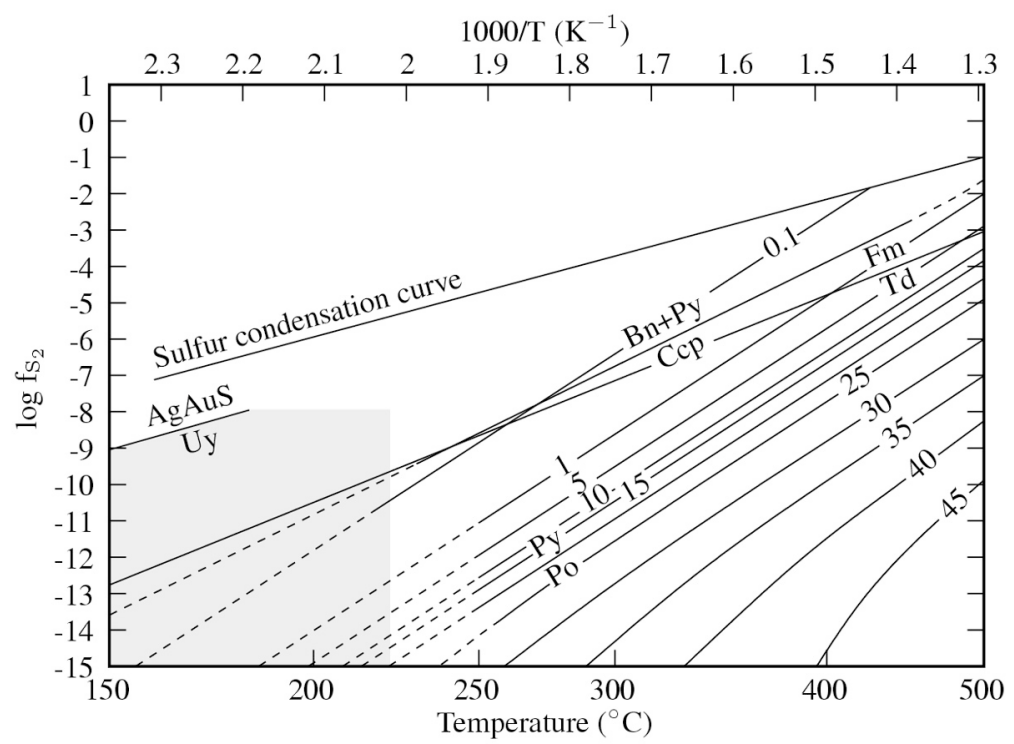

FIG. 9. Conditions of deposition of the sulfide paragenesis in terms of temperature and sulfur fugacity. Symbols: Bn: bornite, Py: pyrite, Ccp: chalcopyrite, Po: pyrrhotite, Fm: famatinite, Td: tetrahedrite, Uy: uytenbogaardtite. Pressure: 1 bar (after Craig \& Barton 1973, Czamanske 1974, Barton et al. 1978).

oxidizing environment of the fluid, close to the $\mathrm{HS}^{-}$ $\mathrm{SO}_{4}{ }^{2-}$ boundary. Such an environment is also favorable for maximum solubility of gold (Hannington \& Scott 1989).

The behavior of gold is interesting. Most gold occurs in the form of Au-Ag alloy. The silver content displays a bimodal distribution (Fig. 3). In most cases, the $\mathrm{Au}-\mathrm{Ag}$ alloy contains 30-55 wt.\% Ag, and the textural relationships suggest a hydrothermal origin. The sample population of low-silver Au-Ag alloy (16-26 wt.\% Ag) is interpreted as being of supergene origin, in accordance with the observations by Greffié et al. (2002). Supergene $\mathrm{Au}-\mathrm{Ag}$ alloy can form under moderately oxidizing conditions where the concentration of chloride is very low and the $\mathrm{pH}$ is carbonate-buffered (Krupp $\&$ Weiser 1992). Another gold-bearing mineral, uytenbogaardtite, also appears in the high-grade grey sulfide - quartz stage. On the basis of phase relations in the system $\mathrm{Ag}-\mathrm{Au}-\mathrm{S}$ between 100 and $185^{\circ} \mathrm{C}$, Barton et al. (1978) suggested that uytenbogaardtite-acanthite is a hypogene assemblage that exsolves from a hightemperature gold-bearing argentite and Ag-rich $\mathrm{Au}-\mathrm{Ag}$ alloy. However, the uytenbogaardtite at Pongkor, which is commonly associated either with low-silver $\mathrm{Au}-\mathrm{Ag}$ alloy, covellite, polybasite and acanthite or with galena, sphalerite and argentian tetrahedrite, is more likely of supergene origin (Greffié et al. 2002). The low-temperature formation of uytenbogaardtite is also indicated by the presence of associated metastable copper sulfide phases, such as yarrowite and spionkopite, which are characteristically produced by low-temperature replacement of primary copper sulfides (Vaughan \& Craig 1997).

The dendritic gold probably formed as a result of low-temperature processes by dissolution of $\mathrm{Au}-\mathrm{Ag}$ alloy and reprecipitation of gold and stromeyerite or mckinstryite from a supergene $\mathrm{Cu}$-enriched fluid. Such a reaction could be written:

$$
\begin{aligned}
& \mathrm{AuAg}+\mathrm{Cu}^{+}+(\mathrm{HS})^{-}+1 / 4 \mathrm{O}_{2} \\
& =\mathrm{Au}^{0}+\mathrm{CuAgS}+1 / 2 \mathrm{H}_{2} \mathrm{O}
\end{aligned}
$$

Deep supergene enrichment of both gold and silver seems to be critical for making Pongkor an economic ore deposit. The two most important veins, Ciurug and Kubang Cicau, have both Ag/Au values close to 10, with no clear-cut enrichment of gold near the top of the systems (Figs. 7b-f). The relatively constant Ag/Au value over about $300 \mathrm{~m}$ of depth is probably a result of the stability of the low-Ag Au-Ag alloy, acanthite, uytenbogaardite, stromeyerite, and mckinstryite in the supergene environment, where $\mathrm{pH}$ is buffered by the hydrothermally deposited carbonate gangue (Krupp \& Weiser 1992). This general pattern of supergene enrichment of both gold and silver is overprinted by sporadic gold-only enrichment in some near-surface pockets of high-grade gold under more oxidizing conditions, where silver-bearing mineral phases become unstable. 


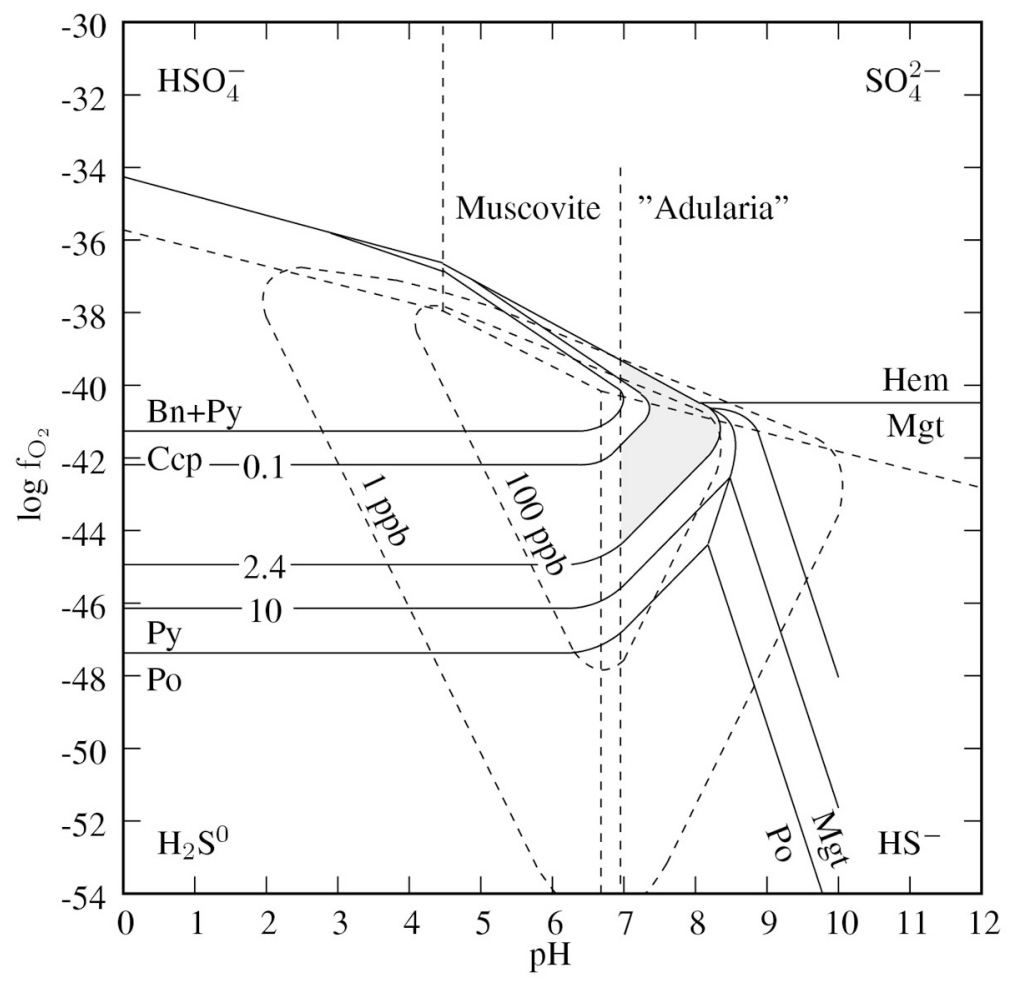

FIG. 10. Diagram showing $f\left(\mathrm{O}_{2}\right)$ versus $\mathrm{pH}$ constructed for $\mathrm{T}=200^{\circ} \mathrm{C}, \Sigma \mathrm{S}=0.005 \mathrm{~mol} / \mathrm{kg}$ $\mathrm{H}_{2} \mathrm{O}$ at standard water vapor pressure. The composition of pyrrhotite is taken as stoichiometric FeS. The shaded areas represent the possible $f\left(\mathrm{O}_{2}\right)-\mathrm{pH}$ region of the Pongkor gold deposit. Symbols as in Figure 8; Mgt: magnetite, Hem: hematite.

\section{ACKNOWLEDGEMENTS}

This contribution is part of a Ph.D. project financed by Deutscher Akademischer Austauschdienst (DAAD). We gratefully acknowledge permission from PT Aneka Tambang (Persero) Tbk to work in the Pongkor mine and to publish these results, and the help of Herian Sudarman Hemes in the field, Klaus Herrmann (TU Clausthal) with the electron-microprobe analyses, Eike Gierth (TU Clausthal) for discussions relating to ore microscopy and for photomicrographs, and Irmina Kris Murwani (Humboldt University, Berlin) for the XRD results. The manuscript benefitted from criticism by Eric Marcoux, Thomas Wagner, and Robert F. Martin.

\section{REFERENCES}

Barton, M.D., Kieft, C., Burke, E.A.J. \& Oen, I.S. (1978): Uytenbogaardtite, a new silver-gold sulfide. Can. Mineral. 16, 651-659.
BARTON, P.B., JR. \& Toulmin, P., III (1966): Phase relations involving sphalerite in the $\mathrm{Fe}-\mathrm{Zn}-\mathrm{S}$ system. Econ. Geol. 61, 815-849.

Basuki, A., Sumanagara, D.A. \& Sinambela, D. (1994): The Gunung Pongkor gold-silver deposit, West Java, Indonesia. J. Geochem. Explor. 50, 371-391.

Benning, L.G. \& Seward, T.M. (1996): Hydrosulphide complexing of $\mathrm{Au}(\mathrm{I})$ in hydrothermal solutions from 150$400^{\circ} \mathrm{C}$ and 500-1500 bar. Geochim. Cosmochim. Acta 60, 1849-1871.

Bente, K. \& DöRIng, T. (1993): Solid-state diffusion in sphalerites: an experimental verification of the "chalcopyrite disease". Eur. J. Mineral. 5, 465-478.

$\&$

(1995): Experimental studies on the solid state diffusion of $\mathrm{Cu}$ and $\mathrm{In}$ in $\mathrm{ZnS}$ and on "disease", DIS (Diffusion Induced Segregations), in sphalerite and their geological applications. Mineral. Petrol. 53, 285-305. 
Browne, P.R.L. \& Ellis, A.J. (1970): The Ohaki-Broadlands hydrothermal area, New Zealand: mineralogy and related geochemistry. Am. J. Sci. 269, 97-131.

Craig, J.R. \& Barton, P.B., JR. (1973): Thermochemical approximations for sulfosalts. Econ. Geol. 68, 493-506.

CZAmanske, G.K. (1974): The FeS content of sphalerite along the chalcopyrite - pyrite - bornite sulfur fugacity buffer. Econ. Geol. 69, 1328-1334.

Dong, G. \& Morrison, G.W. (1995): Adularia in epithermal veins, Queensland: morphology, structural state and origin. Mineral. Deposita 30, 11-19.

Gammons, C.H. \& Williams-Jones, A.E. (1995): Hydrothermal geochemistry of electrum: thermodynamic constraints Econ. Geol. 90, 420-432.

GrefFié, C., BAilly, L. \& MilÉSI, J.-P. (2002): Supergene alteration of primary ore assemblages from low-sulfidation $\mathrm{Au}-\mathrm{Ag}$ epithermal deposits at Pongkor, Indonesia, and Nazareno, Perú. Econ. Geol. 97, 561-571.

Hannington, M.D. \& ScotT, S.D. (1989): Sulfidation equilibria as guides to gold mineralization in volcanogenic massive sulfides: evidence from sulfide mineralogy and the composition of sphalerite. Econ. Geol. 84, 1978-1995.

Hedenquist, J.W., Arribas, A., Jr. \& GonZalez-Urien, E. (2000): Exploration for epithermal gold deposits. Rev. Econ. Geol. 13, 245-277.

Johnson, J.W., Oelkers, E.H. \& Helgeson, H.C. (1992): SUPCRT92: a software package for calculating the standard molal thermodynamic properties of minerals, gases, aqueous species, and reactions from 1 to 5000 bars and 0 to $1000^{\circ}$ C. Comput. Geosci. 18, 899-947.

KRUPP, R.E. \& WeISER, T. (1992): On the stability of goldsilver alloys in the weathering enviroment. Mineral. Deposita 27, 268-275.

Marcoux , E. \& MilÉSI, J.-P. (1994): Epithermal gold deposits in West Java, Indonesia: geology, age and crustal source. J. Geochem. Explor. 50, 393-408.

Sitorus, T. \& Simandjuntak, M (1996): The epithermal Au-Ag-(Mn) deposit of Pongkor (West Java, Indonesia). Indon. Mining J. 2, 1-17.

Milési, J.-P., Marcoux, E., Sitorus, T., Simanduuntak, M., LEROY, J. \& BAILlY, L. (1999): Pongkor (west Java, Indonesia): a Pliocene supergene-enriched epithermal $\mathrm{Au}-\mathrm{Ag}-$ (Mn) deposit. Mineral. Deposita 34, 131-149.
Mohan, W.A.J. \& Finlayson, J.B. (1972): The chemistry of the Broadlands geothermal area, New Zealand. Am. J. Sci. 272, 48-68.

PlumleE, G.S. (1994): Fluid chemistry evolution and mineral deposition in the main-stage Creed epithermal system. Econ. Geol. 89, 1860-1882

RuCKLIDGE, J. \& STUMPFL, E.F. (1968): Changes in the composition of petzite $\left(\mathrm{Ag}_{3} \mathrm{AuTe}_{2}\right)$ during analysis by electron probe. Neues Jahrb. Mineral., Monatsh., 61-68.

SchwarTZ, G.M. (1935): Relations of chalcocite - stromeyerite - argentite. Econ. Geol. 30, 128-146.

ScotT, S.D. \& BARnES, H.L. (1971): Sphalerite geothermometry and geobarometry. Econ. Geol. 66, 653-669.

SHIKAZONo, N. (1978): Selenium content of acanthite and the chemical environments of Japanese vein-type deposits. Econ. Geol. 73, 524-533.

(1985): A comparison of temperatures estimated from the electrum - sphalerite - pyrite - argentite assemblage and filling temperatures of fluid inclusions from epithermal Au-Ag vein-type deposits in Japan. Econ. Geol. 80, 1415-1424.

Simon, G., Kesler, S.E. \& Essene, E.J. (1997): Phase relations among selenides, sulfides, tellurides, and oxides. II. Applications to selenide-bearing ore deposits. Econ. Geol. 92, 468-484.

Sujatmiko \& Santosa, S. (1992): The Geologic Map of the Leuwidamar Quadrangle, Jawa. Pusat Penelitian dan Pengembangan Geologi.

TAYLOR, S.R. \& McLennan, S.M. (1995): The geochemical evolution of the continental crust. Rev. Geophys. 33, 241265.

VAughan, D.J. \& CRAIG, J.R. (1997): Sulfide ore mineral stabilities, morphologies, and intergrowth textures. In Geochemistry of Hydrothermal Ore Deposits (H.L. Barnes, ed.). John Wiley \& Sons, Inc., New York, N.Y. (367-434).

Wood, S.A. (1998): Calculation of activity-activity diagrams and $\log f \mathrm{O}_{2}-\mathrm{pH}$ diagrams. Rev. Econ. Geol. 10, 81-96.

Received September 21, 2002, revised manuscript accepted December 11, 2002. 